\title{
AVALIAÇÃO DA MECANIZAÇÃO SOBRE O MERCADO DE TRABALHO NA LAVOURA DA CANA-DE-AÇÚCAR
}

\author{
Carolina Rocha Batista ${ }^{1}$ \\ Ítalo do Nascimento Mendonça ${ }^{2}$
}

\begin{abstract}
RESUMO: A evolução da mecanização no setor produtor da cana-de-açúcar vem crescendo de maneira significativa nos estados brasileiros. O presente trabalho pretende avaliar como essa mecanização afetou na evolução do número de empregados em dois períodos distintos: 2004-2008 e 2014-2018, assim como o perfil dos trabalhadores. Utilizou-se dados da Pesquisa Nacional por Amostras de Domicílios como fonte de dados neste trabalho. Evidenciou-se que os trabalhadores, em sua maioria, possuíam as seguintes características: homens, brancos ou pardos, com ensino fundamental ou médio, adultos, concentrados na grande região CentroSul. Com a evolução da mecanização em todas as regiões do país - destaque para a região Norte, que alcançou um percentual de 100\% de colheita mecanizada observou-se que houve uma significativa redução no número de ocupados nas lavouras da cana-de-açúcar entre os dois períodos - queda de 58\% de 2008 a 2018 - e também que ocorreu aumento no número de trabalhadores mais qualificados e uma leve redução na quantidade de trabalhadores elementares.
\end{abstract}

Palavras-Chave: Cana-de-Açúcar; Mecanização; Mercado de Trabalho; Agricultura.

ABSTRACT: The evolution of mechanization in the sugarcane producing sector has been growing significantly in the Brazilian states. This paper aims to evaluate how this mechanization affected the evolution of the number of employees in two different periods: 2004-2008 and 2014-2018, as well as the workers profile. Data from the Pesquisa Nacional por Amostra de Domicilios were used as data source in this paper. Most of the workers had the following characteristics: men, white or brown, with elementary or high school, adults, concentrated in the great Center-South region. With the evolution of mechanization in all regions of the country - highlighting the North region, which reached a percentage of $100 \%$ of mechanized harvest - it was observed that there was a significant reduction in the number of occupied in sugarcane crops among both periods - a 58\% drop from 2008 to 2018 - and also that there was an increase in the number of more skilled workers and a slight reduction in the number of elementary workers.

Keywords: Sugar Cane; Mechanization; Labor Market; Agriculture.

\footnotetext{
${ }^{1}$ Graduação em Ciências Econômicas (PUC/Minas). Mestranda em Economia (UNIFAL-MG). E-mail: carolrb15@hotmail.com.

2 Bacharel em Ciências Econômicas com ênfase em Controladoria (UNIFAL-MG). Bacharel Interdisciplinar em Ciência e Economia (UNIFAL-MG). Técnico em Informática (CEFET/MG). E-mail: italovga@hotmail.com.
} 


\section{INTRODUÇÃO}

A lavoura da cana-de-açúcar é, historicamente, uma das mais expressivas na atividade agrícola do país. Sua evolução perpassa séculos de economia colonial, de império e avança até o período recente, que está sendo marcado por inúmeras transformações tecnológicas em toda a atividade nos canaviais.

Essas mudanças oriundas do progresso técnico fazem parte de uma revolução incessante que a dinâmica capitalista implementa na economia global. Este fator desafia as atividades agrícolas - aqui, inclui-se a cultura da cana-deaçúcar - a repensarem as engrenagens de seu funcionamento para se tornarem mais competitivas e eficientes, visando atender as conjunturas de mercados nacionais e internacionais.

Por sua vez, o mercado de trabalho das pessoas ocupadas na cana-deaçúcar é notadamente afetado por tais transformações. Logo, as mudanças nos processos produtivos dessa lavoura resultam em novas configurações de trabalho que, aliadas às alterações no mercado de trabalho como um todo, podem ocasionar desequilíbrios no número de postos de trabalhos desse setor.

A mecanização da lavoura da cana-de-açúcar é um dos exemplos mais significativos de transformações que afetam o emprego em atividades agrícolas. $\mathrm{O}$ fato de máquinas poderem substituir um contingente de trabalho humano é justamente um resultado das inovações tecnológicas exponenciais das últimas décadas e sua influência no aumento de pessoas desempregadas pode ser um problema social da geração atual.

O presente trabalho pretende avaliar como essa mecanização afetou a evolução do número de empregados em dois períodos distintos: 2004-2008 e 20142018, assim como o perfil dos trabalhadores Para isso, comparam-se distintas conjunturas econômicas: o período de 2004 a 2008, no qual há um aquecimento no mercado de trabalho; e o período de 2014 a 2018, no qual há a reversão e retração do mercado de trabalho. A comparação entre períodos de aquecimento e contração do mercado de trabalho ajuda a alcançar o objetivo estabelecido, pois se espera uma maior contratação de trabalhadores no primeiro período e uma menor contratação no segundo, visto que a partir do começo da década de 2000 foi constatado pela literatura maior mecanização no setor. 
Assim, parte-se da hipótese de que a mecanização tende a influenciar negativamente o saldo de postos de trabalho elementares ou básicos nessa atividade. Por outro lado, podem significar aumento de contratações de empregados que possuem maior qualificação e preparo para o trabalho.

O trabalho se justifica na medida em que as transformações recentes na lavoura da cana-de-açúcar podem ser analisadas através do corte temporal definido entre os dois períodos. Ademais, evidencia-se ao longo da pesquisa que há uma pressão ambiental e social para que o corte manual da cana-de-açúcar seja eliminado, devido às consequências à natureza e à saúde dos trabalhadores empregados neste setor.

Além desta introdução, o trabalho apresenta como as transformações técnicas impulsionadas pela ótica capitalista se inserem no contexto da lavoura da cana-de-açúcar. Em seguida, discute-se como as transformações ambientais causados pela colheita da cana-de-açúcar na forma de queimadas foi alvo de pressões por parte de ambientalistas para o fim de tal prática - o que significaria aumento da mecanização das lavouras. Posteriormente, discute-se a evolução recente do mercado de trabalho da cana-de-açúcar e como a introdução da mecanização reformulou os processos produtivos, bem como, seus impactos no emprego. Por fim, apresenta-se a análise de dados e os resultados da pesquisa, seguidos pelas considerações finais do trabalho.

\section{A MECANIZAÇÃO NO CONTEXTO DA DINÂMICA CAPITALISTA}

A colheita da cana-de-açúcar é uma das atividades mais antigas desenvolvidas em terras brasileiras. Desde a colônia, muitas mudanças aconteceram no exercício de tal negócio. Essa evolução perpassa progressos técnicos, mudanças culturais e laborais, alterações no meio ambiente e no uso do solo.

Entender a dinâmica da cultura da cana-de-açúcar no período recente da economia brasileira requer um acompanhamento gradual de como tal atividade vem sendo modificada por mudanças no que tange ao progresso técnico. É importante ressaltar a busca incessante por melhorias de competitividade - o que passa pela evolução do capital. Além disso, é preciso destacar as mudanças internas na 
realização de tal cultura, seja para atender agendas ambientais ou mesmo por consequências das discussões sobre o impacto no trabalho empregado em tal plantio.

No tópico a seguir reflete-se sobre como a ótica capitalista influencia a busca por competitividade e eficiência, através da evolução do progresso técnico e da inovação. Neste intuito, debate-se como a cultura da cana-de-açúcar é inevitavelmente afetada por mudanças nesse sentido.

\subsection{O PROGRESSO TÉCNICO, A PRODUTIVIDADE E A COMPETITIVIDADE DAS EMPRESAS}

$\mathrm{Na}$ análise das várias concepções sobre o capitalismo, sua origem e evolução tem-se uma abordagem sobre o modo de produção em que ocorre a lei geral da acumulação capitalista. Esta percepção foi fortemente discutida no contexto da transição do feudalismo para o capitalismo sendo que a partir de Marx, analisa-se a relação entre a acumulação de capital e crescimento da produtividade.

A influência progressista do capitalismo se baseia - devido a alguma qualidade duradoura de sua natureza - no sistema prosperado pela inovação contínua. Tal inovação requer a maior eficiência possível dos fatores de produção, isto é, aumento da produtividade social do trabalho, de forma a torná-lo mais potente e pronto para a competição estabelecida pela lógica e dinâmica capitalista.

De acordo com Marx (1996, p. 254), em sua análise da Lei Geral da Acumulação Capitalista, "o grau de produtividade social do trabalho se expressa no volume relativo dos meios de produção que um trabalhador, durante um tempo dado, com o mesmo dispêndio de força de trabalho, transforma em produto". Esta é a essência que Marx coloca sobre a produtividade da força de trabalho na dinâmica capitalista, ou seja, conforme o progresso técnico modifica as relações entre capital e trabalho, a produtividade aumenta de acordo com a realocação da razão capital/trabalho em sua eficiência.

Além da visão acima mencionada que incorpora a análise do trabalho como componente subordinado à variação da quantidade de capital utilizado na produção, existe também a relação do desenvolvimento do processo de globalização e a reestruturação do capitalismo. Isto conduziu o acirramento da concorrência 
internacional dada pela revolução tecnológica e produtiva, o que dificultou ainda mais a competitividade dos indivíduos.

Conforme explicam Krein et al (2018), pela ordem instaurada através da nova estrutura financeira internacional e de revolução técnico-produtiva, o novo padrão de competição, contribuiu para a centralização do controle empresarial e estabeleceu uma nova distribuição espacial com as chamadas cadeias globais de valor. Além disso, o processo de financiamento das empresas está mais disputado diante do desenvolvimento do mercado financeiro que teve enorme impulso ao longo das últimas décadas.

A essa dinâmica atrelada à inovação tecnológica e à ideia de reestruturação do capitalismo global, Beluzzo e Mazzucchelli (2009) consideram que a inovação é arma de combate ao concorrente. Assim, a redução do tempo de trabalho aparece como condição necessária para avançar na competição.

Além de Marx, outro expoente que estuda como o capitalismo se reinventa em sua própria dinâmica é o austríaco Joseph Alois Schumpeter. Em seus trabalhos, este autor buscou entender como a inovação é capaz de reformular a ótica capitalista por meio dos ciclos de expansão e retração desse sistema.

Schumpeter é um dos pioneiros da economia neoclássica a retirar a hipótese de estacionariedade do crescimento econômico. Com isso, nega-se a estática econômica, amplia-se a expansão da riqueza por meio de um processo de destruição criativa (OLIVEIRA, 2014).

Segundo Teodósio et al (2006, p.39), o economista austríaco centra suas análises "na chamada 'destruição criativa' e no impacto da ação dos empreendedores em gerar inovações radicais, capazes de destruir velhos mercados e abrir novas frentes de competitividade para empresas nascentes". Logo, a ação inovadora tem a capacidade de gerar um novo contexto de competitividade dentro da economia. Por sua vez, as empresas devem se adaptar a tal mudança para poder sobreviver. Aquelas que não conseguem se enquadrar em um novo padrão de competitividade são destruídas e, por outro lado, as que se adaptam tem em seu cerne que a inovação é crucial para sobreviverem e competirem umas com as outras, sempre maximizando seu lucro e reduzindo os custos em suas atividades.

Destaca-se, nesse ponto, que a teoria de Schumpeter tende a ser evolucionária. Ele mesmo, em sua obra "Capitalismo, socialismo e democracia", cita 
que Marx já havia realçado esse caráter evolutivo antes dele, mas sem uma análise contundente sobre tal fato (SCHUMPETER, 1961). Para Schumpeter, é esse processo de destruição criativa o responsável pela continuidade e renovação do capitalismo no mundo atual, na medida em que o que ele chama de "revoluções" vão acontecendo na economia e transformando a relação entre indivíduos, indústrias e nações.

\begin{abstract}
Essas revoluções não são permanentes, num sentido estrito; ocorrem em explosões discretas, separadas por períodos de calma relativa. O processo, como um todo, no entanto, jamais para, no sentido de que há sempre uma revolução ou absorção dos resultados da revolução, ambos formando o que é conhecido como ciclos econômicos. Este processo de destruição criadora é básico para se entender o capitalismo. É dele que se constitui o capitalismo e a ele deve se adaptar toda a empresa capitalista para sobreviver (SCHUMPETER; 1961; p. 110).
\end{abstract}

Trazendo essa análise para entender como a indústria é afetada por transformações inovadoras é fato que haverá ganhadores e perdedores nesse processo. Em relação a isso, Costa (2006, p. 8) afirma que "as inovações, ao se colocarem como alternativas a produtos e processos antigos, fazem com que esses últimos percam espaço no mercado, sucateando capacidade instalada e destruindo postos de trabalho [...]". Desta forma, ao mesmo tempo que a inovação é uma atividade benéfica ao progresso social, pode ocasionar graves desequilíbrios no mercado de trabalho e pode demandar tremendos esforços de investimentos que nem todos as economias são capazes de almejar.

As ondas de transformações econômicas - períodos em que ocorrem um ciclo completo de destruição criativa - acontecem em um espaço de tempo cada vez mais curto. Esse conceito foi, inicialmente, apresentado por Kontradiev (um economista russo) e utilizado por Schumpeter para apoiar sua teoria. Por essa ideia, há uma visão de que o capitalismo tem ciclos de contração e retração econômica. Porém, o progresso tecnológico é evidente entre os ciclos e beneficia a expansão de riqueza e a produtividade da economia.

Ao analisar-se a discussão de inovação e competitividade para a indústria nacional, denota-se que, mesmo sendo periférica, a economia brasileira está sujeita às transformações tecnológicas e inovadoras que acontecem ao redor do globo e 
até mesmo aos ciclos de expansão e contração da economia, absorvidos de maneira diferente por cada nação.

Mesmo ainda sendo uma expressiva exportadora de produtos primários, a economia brasileira se insere no ciclo de inovações descrito acima. Alguns autores, como Prebisch (2000), indicam que economias com grande potencial agrícola tendem a ser prejudicadas quando em confronto com economias essencialmente industrializadas. Porém, a tese estruturalista de desenvolvimento "baseada nas trocas desiguais de comércio internacional não explica o comportamento do moderno setor agrícola, o qual é capaz de gerar progresso técnico e valor agregado, bem como justificar o crescimento de regiões dinâmicas agroexportadoras - o paradoxo de Prebisch" (VIEIRA et al; 2016; p.624). Ou seja, até mesmo economias com grande participação do setor agrícola passam pelo processo de inovação e dinamização de suas atividades.

Na produção de cana-de-açúcar, tal mecanismo não se apresenta de modo diferente. As recentes mudanças neste setor e o afastamento do Estado em sua proteção, implicam um reajuste das instituições envolvidas com os produtos que são gerados a partir da cana-de-açúcar. Segundo Moraes (2007a), desde 1999 os preços dos produtos oriundos da cultura da cana-de-açúcar são estabelecidos em livre mercado, impondo um novo padrão de competição às usinas de álcool e açúcar, fazendo-as procurar novas estratégias de competição com o intuito de reduzir custos e aumentar sua produtividade para sobreviverem neste novo ambiente competitivo.

Desse modo, a partir dessas mudanças de curso forçado na atividade da cana-de-açúcar, seja por pressões ambientais, por melhorias na saúde dos trabalhadores ou mesmo por necessidades de sobrevivência e luta por competitividade, o setor da cana-de-açúcar vem passando por transformações inevitáveis. Estas transformações incluem, por conseguinte, o uso de tecnologia para mecanização da colheita.

$\mathrm{Na}$ seção a seguir, discute-se rapidamente como as atividades nos canaviais foram gradualmente passando por modificações. Isto ocorreu para atender a uma agenda ambiental de preservação e minimização de prejuízos, não só ao meio ambiente, mas também à saúde dos trabalhadores. 


\subsection{A QUESTÃO AMBIENTAL}

Ao se analisar o curso da evolução da colheita da cana-de-açúcar, deve-se evidenciar os impactos que essa atividade gera no meio ambiente e também para a saúde dos trabalhadores envolvidos nesse processo.

Em um passado recente, a principal forma de dinamizar a colheita da canade-açúcar foi o uso da queimada controlada, que permite o melhor manuseio e corte da cana, aumentando a produtividade e a eficiência diária do trabalhador. Porém, essa queimada é nociva à saúde desses empregados - podendo causar problemas respiratórios, devido à emissão de monóxido de carbono - e, principalmente, ao meio ambiente (SCOPINHO et al, 1999).

Logo, essa prática danosa empregada nos canaviais foi alvo de grande repercussão entre a sociedade, principalmente entre os defensores do meio ambiente. Segundo Moraes (2007b, p. 606), no que tange aos impactos para o meio ambiente, citam-se "os efeitos sobre a qualidade do ar nas áreas urbanas e rurais, sobre o clima global, sobre a oferta de água, ocupação e preservação do solo, emprego de agrotóxicos e fertilizantes". Portanto, é evidente que as queimadas praticadas na lavoura da cana trazem prejuízos significativos para o meio ambiente e para a sociedade como um todo.

A crescente preocupação com as questões ambientais incentivou mudanças na colheita da cana-de-açúcar. Com a possibilidade de mecanização da colheita, além das vantagens econômicas passíveis de serem obtidas, diminuem-se os reflexos negativos no meio ambiente e na saúde do trabalhador (LIMA, 2016). Além disso, segundo Wissman e Shikida (2017), tal atitude reflete uma preocupação do setor canavieiro em cada vez mais ser referenciado como uma atividade de 'produção limpa' e que tem como resultado um 'produto limpo'.

Segundo Ramalho (2014), a luta contra o fim das queimadas se iniciou na década de 1990 e culminou, em 2007, com um acordo entre o governo do Estado de São Paulo e os usineiros. Este acordo estipulou o fim das queimadas em áreas onde a mecanização for possível para o ano de 2021; já em áreas onde a mecanização não for possível, estima-se que a proibição total das queimadas ocorrerá em 2031.

Com o incentivo institucional para a proibição da queima da cana e a fiscalização da legislação trabalhista, Lima (2010), aponta que a competitividade 
entre as usinas tende a dinamizar o processo de mecanização nas lavouras da cana-de-açúcar. Com isso, há impactos diretos no meio ambiente e reflexos no mercado de trabalho deste agronegócio.

Em se tratando dessa gradual eliminação das queimadas, Ribeiro e Ficarelli (2010, p.52) apontam que isso é "uma vitória para a população que habita as zonas sucroalcooleiras, incluindo os cortadores, porém, socialmente, a mecanização poderá marginalizar essa população, se propostas alternativas de trabalho e de inclusão social não forem pensadas, planejadas e implementadas". Ou seja, a mecanização da colheita pode possuir aspectos positivos no que tange ao meio ambiente, mas tem o potencial de trazer impactos negativos nas características do mercado de trabalho desse setor.

A mecanização da colheita da cana é uma atividade inerente ao processo de evolução desse ramo e surge como potencial redutora de impactos ambientais e também na saúde dos trabalhadores. Neste sentido, busca-se se entender como a mecanização afetou o mercado de trabalho da cana-de-açúcar.

Logo, a reflexão é importante para visualizar como tal atividade foi sofrendo modificações não só para atender a essa agenda ambiental, mas também para atingir objetivos de progresso técnico e de competitividade próprios da modernização e do desenvolvimento que o mundo se encontra e que o Brasil também busca alcançar, para não ficar atrás nesse expressivo mercado (ALMEIDA, 1995). Ou seja, é importante entender como a introdução da mecanização dinamizou o mercado de trabalho da cana-de-açúcar.

Na próxima seção será debatido como a mecanização da colheita da cana vem ocorrendo ao longo dos últimos anos e seus efeitos no que tange ao impacto no mercado de trabalho do setor.

\subsection{A EVOLUÇÃO DA MECANIZAÇÃO}

Por ser um setor dinâmico, a plantação da cana-de-açúcar oferece a oportunidade de gerar produtos como o açúcar, o etanol, etanol anidro e etanol hidratado, inserindo o Brasil na condição mundial de maior produtor de cana-deaçúcar. Tal dinamismo e impacto do setor na agricultura do país exige a 
necessidade de inovação constante, garantido competitividade e eficiência das usinas.

A mecanização no setor produtor da cana-de-açúcar se justifica por três medidas principais: redução da poluição ao meio ambiente causada pelas queimadas das lavouras, eliminação da situação precária em que se sujeitam os trabalhadores do setor canavieiro e aumento da produtividade na produção. Entretanto, de acordo com Moraes (2007b), por razões como declividade das terras, capacidade de compras de máquinas pelos produtores, estrutura fundiária e movimentos sindicais, a adoção da colheita mecanizada se dá de maneira desigual entre as regiões produtoras brasileiras.

De todas as etapas da produção da cana-de-açúcar, a que mais sofre alterações por motivos de mudanças socioambientais e redução de custos é a colheita, última etapa do ciclo da cultura. Dos tipos de colheitas existentes, a colheita manual é a que o trabalhador realiza o corte braçal da cana. O percentual médio de corte manual da cana passou de $75,6 \%$ na safra de $2007 / 2008$ para $8,2 \%$ na safra de 2018/2019 (BRASIL, 2019).

A colheita manual pode ser realizada de duas formas: com queima prévia ou colheita da cana crua. A primeira visa a eliminação da palha reduzindo o esforço físico do trabalhador, o que acarreta em aumento da produtividade. Já a colheita da cana crua, de acordo com Brasil (2019, p. 44) "dificulta o trabalho, pois reduz o rendimento, o que acaba por inviabilizar economicamente a operação e, além disso, com a relutância dos cortadores em aceitar esse tipo de trabalho, torna-se uma opção inviável." Desta forma, devido ao impacto ao meio ambiente causado pela colheita manual, conclui-se que as vantagens da mecanização não só viabilizam o aumento da produtividade, como também amenizam as discussões acerca dos reflexos causados pelas queimas ao meio ambiente.

Para observação dos dados da evolução da mecanização do país, nos Gráficos 1 e 2 mostram-se o percentual de área mecanizada compreendido entre as safras de 2012/2013 e 2018/2019 nas duas grandes regiões brasileiras: centro/sul e norte/nordeste e por macrorregiões geográficas. 


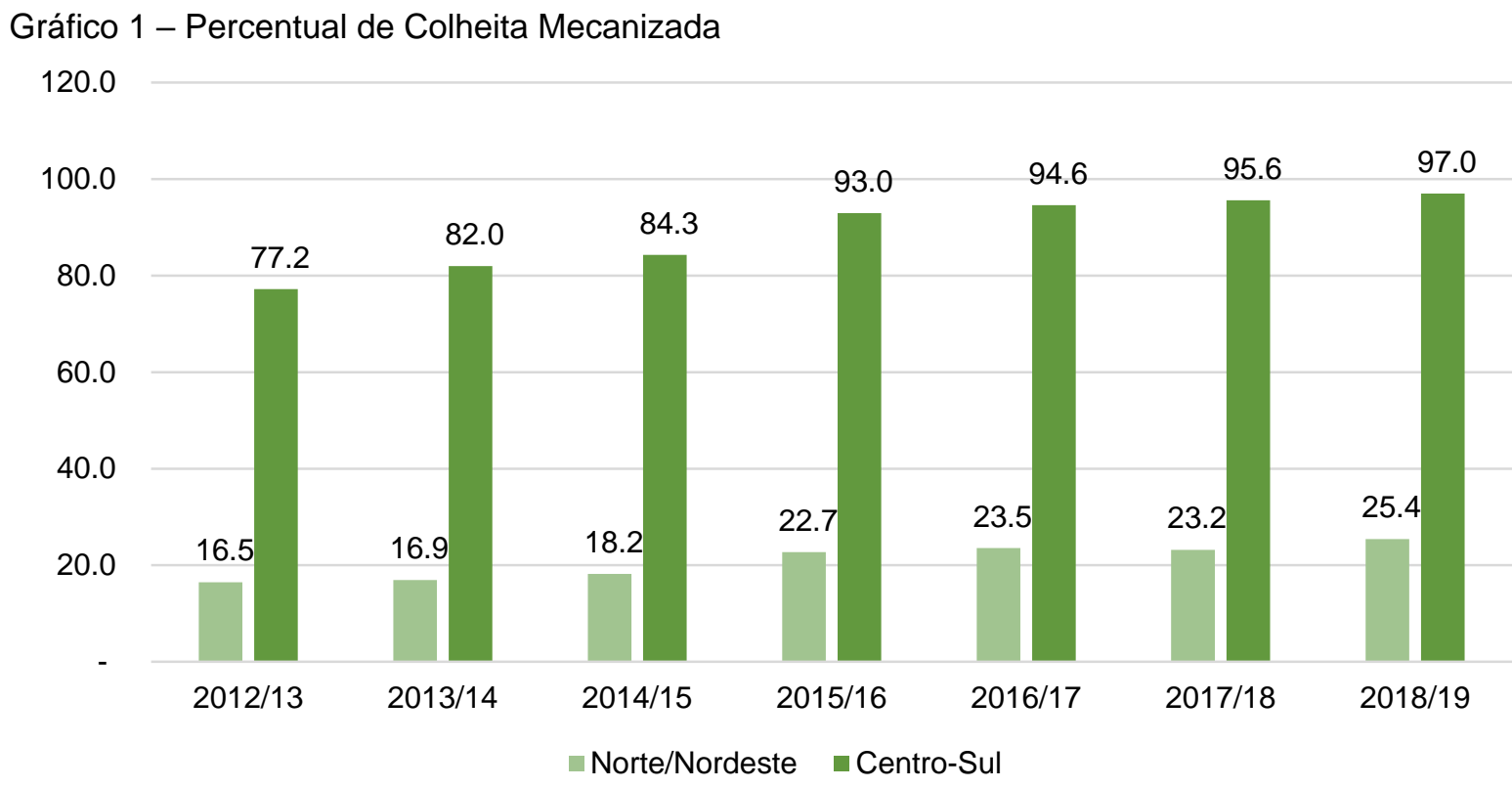

Fonte: elaborado pelos autores, com dados extraídos da CONAB (Brasil, 2019b).

Por meio do Gráfico 1 observa-se que a maior região com colheita mecanizada é a centro-sul justificada pelo relevo que beneficia a mecanização. Já na região Norte/Nordeste o menor percentual de mecanização se justifica pelas áreas de produção com declives acentuados e maior disponibilidade de mão de obra (BRASIL, 2019b).

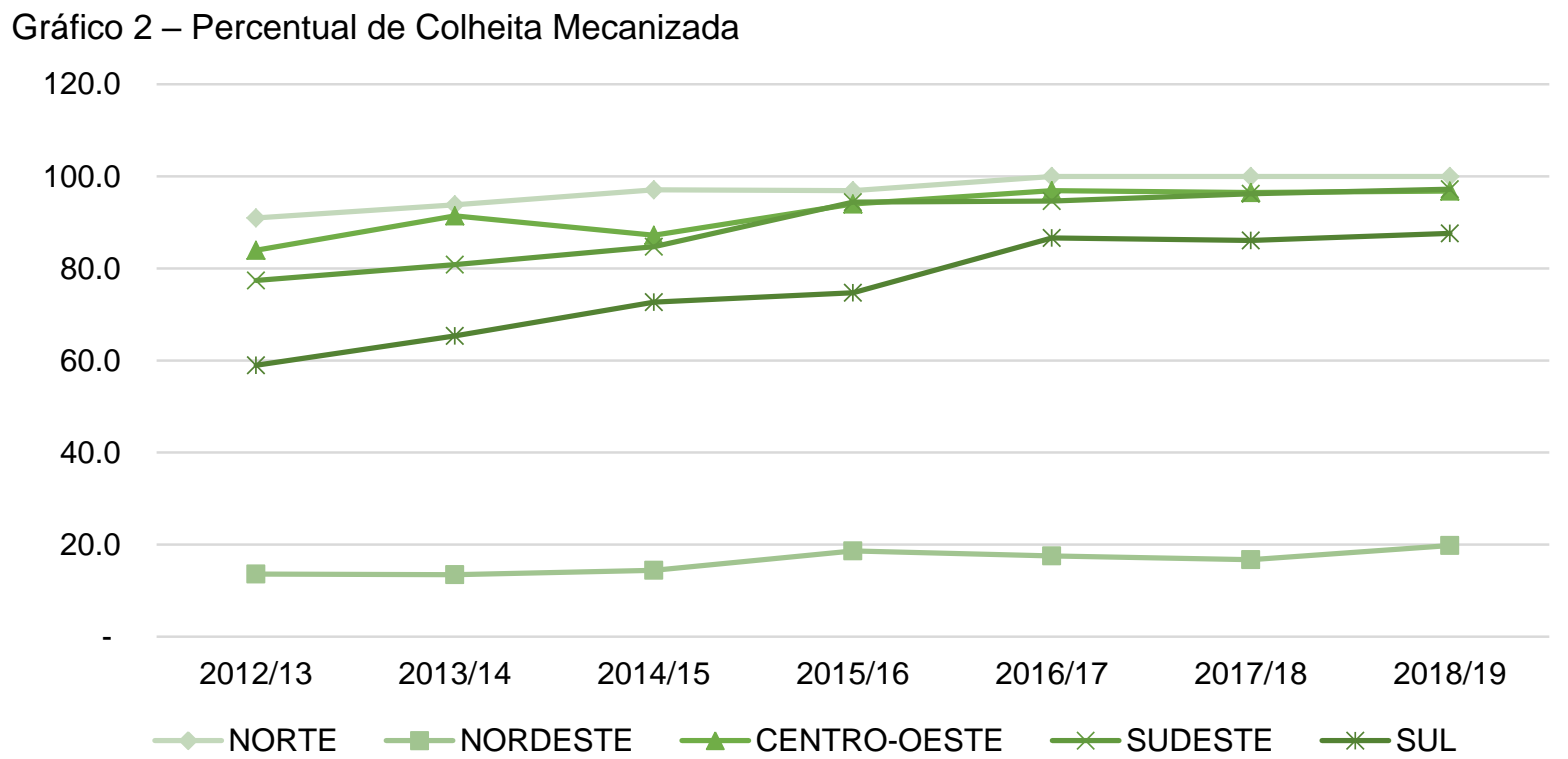

Fonte: elaborado pelos autores, com dados extraídos da CONAB (Brasil, 2019b). 
Pelo Gráfico 2 anterior, a região Norte aparece com o maior índice de mecanização. Entretanto, quando somada as duas grandes regiões: Norte e Nordeste, o baixo percentual da região Nordeste faz com que a região Centro-Sul se sobressaia em relação a Norte/Nordeste. Dentro destas regiões, os três maiores percentuais de mecanização encontram-se nos estados Mato Grosso do Sul, Minas Gerais e São Paulo, com percentual de mecanização da colheita, respectivamente $99,1 \%, 99,5 \%$ e $95,9 \%$ para a safra de $2017 / 2018$.

$\mathrm{Na}$ Tabela 1, estão apresentados os números de colheitadeiras por região máquinas que eliminam o uso de trabalhadores na função de carregador. Evidenciase o que este tipo de maquinário está mais presente nas regiões Centro-Oeste e Sudeste - local onde a plantação da cana é mais concentrada se comparada à outras regiões. Os estados que apresentaram maior número de máquinas foram: São Paulo, Minas Gerais e Goiás na safra de 2017/2018.

Tabela 1 - Número de colheitadeiras por região

\begin{tabular}{|c|c|c|c|c|c|c|c|}
\hline REGIÃO & 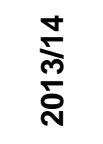 & $\frac{\frac{n}{\sigma}}{\frac{\sigma}{\sigma}}$ & $\frac{0}{\frac{1}{50}}$ & $\frac{N}{0}$ & $\frac{\infty}{\stackrel{\infty}{N}}$ & $\frac{\sum_{\infty}^{\infty}}{\sum_{\text {N }}^{\infty}}$ & Variação \\
\hline NORTE & 55 & 54 & 53 & 56 & 52 & 51 & $-7 \%$ \\
\hline NORDESTE & 119 & 131 & 148 & 145 & 146 & 143 & $20 \%$ \\
\hline CENTRO-OESTE & 1.153 & 1.325 & 1.415 & 1.258 & 1.239 & 1.257 & $9 \%$ \\
\hline SUDESTE & 3.774 & 3.865 & 4.156 & 4.302 & 4.031 & 3.902 & $3 \%$ \\
\hline SUL & 322 & 410 & 397 & 434 & 423 & 412 & $28 \%$ \\
\hline BRASIL & 5.423 & 5.785 & 6.169 & 6.195 & 5.891 & 5.765 & $6 \%$ \\
\hline
\end{tabular}

Fonte: elaborado pelos autores com dados extraídos da CONAB, $2019 \mathrm{~b}$.

Apesar da concentração do número de máquinas estar nas regiões CentroOeste e Sudeste, isto não implica necessariamente que essas são as regiões mais mecanizadas do país, visto que conforme apontado pelo Gráfico 2, o Norte do país é a região mais mecanizada. Ressalta-se também, pela Tabela 1, que as regiões Nordeste e Sul foram as que mais incrementaram o uso de máquinas colheitadeiras entre as safras de 2013 e 2018.

Discorre-se agora sobre a evolução do mercado de trabalho na cana-deaçúcar e como o trabalho foi sendo afetado por mudanças inerentes à própria 
organização da atividade açucareira. Destaca-se a mecanização como grande influenciadora em mudanças nas atividades diárias dos trabalhadores nas lavouras.

\subsection{O MERCADO DE TRABALHO}

O entendimento da consolidação do mercado de trabalho da cana-de-açúcar se inicia com a entrada do produto no país e sua evolução histórica. A partir disso é necessário a discussão da regulamentação das leis específicas a este setor produtor.

O sentido da colonização foi, de uma maneira profunda, detalhado nas palavras de Caio Padro Júnior. De acordo com o autor, a intenção de transformar o Brasil em uma colônia, era unicamente a de fornecer gêneros tropicais ou minerais para o mercado europeu. O açúcar era um destes produtos, que foi cultivado inicialmente para produção e exportação. A grande propriedade, a monocultura e o trabalho escravo, foram formas que se combinavam e completavam durante o século XVI para concretização da nova ordem mundial, com gêneros de grande valor comercial e alta lucratividade (PRADO JÚNIOR, 2011).

O êxito da produção de açúcar pela grande empresa europeia, deve-se a um conjunto de fatores favoráveis que foram construídos ao longo do tempo, como a técnica de produção, a criação de mercado, o financiamento e a mão de obra. Primeiramente, os portugueses já haviam produzido o açúcar nas ilhas do Atlântico, no qual foram aperfeiçoadas as técnicas de produção e o desenvolvimento de uma indústria de equipamentos para construção dos engenhos açucareiros. A criação do mercado se desenvolveu com a etapa produtiva, que ficava a cargo dos lusitanos. $O$ recolhimento em Lisboa do açúcar bruto e a distribuição por toda a Europa estava a cargo dos flamengos. O financiamento requerido pela empresa açucareira veio especialmente dos Países Baixos, com a contribuição dos capitais holandeses. Por fim, o problema da escassez de mão-de-obra, foi contornada também pelos portugueses, que já tinham um vasto conhecimento do mercado africano de escravos (FURTADO, 2003).

Com uma população de cerca de 60 mil habitantes, o Brasil do século XVI havia se transformado em uma colônia de agricultura tropical capitalizada pela Europa. Os fatores que levaram o Brasil a ser uma economia açucareira colonial de 
sucesso são fatores climáticos, políticos, econômicos e geográficos, transformando assim, as capitanias de Pernambuco e Bahia em grandes capitanias produtoras (SCHWARTZ, 2004).

Instaurado o produto no país e o desenvolvimento de suas técnicas produtivas, tem-se a história da evolução do mercado de trabalho. De acordo com Barbosa (2016) o mercado de trabalho no Brasil, foi dividido em três grandes períodos: a colônia e o não mercado de trabalho, a construção do mercado de trabalho no Brasil de 1850 a 1930 e, por último, nacionalização e consolidação do mercado de trabalho de 1930 a 1980. Para o autor, estes três períodos são marcados pela grave heterogeneidade estrutural e também o aprofundamento das várias classes conhecidas como "classe média assalariada, operários com acesso aos direitos básicos do trabalho, operários precários, além de um amplo segmento formado pelo subproletariado, classe dependente urbana ou ralé, conforme a definição" (BARBOSA, 2016, p.26).

Além destes três períodos considerados por Barbosa (2016) temos também mudanças significativas citadas por Krein et al (2018), caracterizando, uma quarta fase do mercado de trabalho no país. Os autores afirmam que a partir de década de 1980 ocorreu uma reconfiguração no desenvolvimento da indústria, impulsionando estruturas produtivas mais organizadas com vistas ao aumento da produtividade atrelada as despesas com direitos trabalhistas, sociais e previdenciários que foram criados. Paralelo a estas mudanças, mesmo numa estrutura configurada pela heterogeneidade da estrutura produtiva, exclusão social e desigualdade regional, as mudanças desta nova fase do mercado de trabalho, contribuíram para o aumento relativo do emprego formal, o que é compatível com a proteção trabalhista, social e previdenciária.

Caracterizando o período posterior à 1980 como a quarta fase em que se encontra o mercado de trabalho no Brasil e inserindo-o no contexto da cana-deaçúcar, pode-se observar que há uma característica principal: a mecanização que vem substituindo o trabalho humano vem sendo acompanhada por uma melhora nas condições de trabalho sob a ótica da colheita manual da cana-de-açúcar. Entretanto, apesar da melhoria destas condições de trabalho, não se pode deixar de lado as avaliações do perfil dos trabalhadores, desemprego resultante da mecanização, 
permanência de trabalho em condições precárias como novas formas de ocupações para os ocupados na área mecanizada.

No entendimento destas avaliações, é de grande importância a análise do estudo da legislação sobre as formas de contratação e condições de trabalho. Por ser um setor que emprega grande número de pessoas, no mercado de trabalho canavieiro, existe a chamada remuneração por produtividade, contratação por terceirização e a ocorrência de migração de outros estados para trabalho na lavoura.

A remuneração por produtividade é garantida pela Consolidação das Leis de Trabalho (CLT), e esta forma de pagamento estimula os trabalhadores a cortarem o máximo de cana possível no mínimo de tempo por eles estabelecido, visto que quanto maior a quantidade de toneladas por trabalhador, maior será a sua remuneração. Se por um lado o estímulo ao aumento da produtividade retorna maiores salários, por outro isso leva a degradação da saúde dos trabalhadores, visto que o esforço físico repetitivo, se dá de maneira excessiva. Além disso, por mais que a Constituição Federal garanta o direito ao salário mínimo, o pagamento por produtividade acaba restringindo que este direito seja, de fato, garantido.

Pelo fato de a remuneração ser garantida por produção, de acordo com dados da ONG Repórter Brasil (2015), um cortador de cana corta, em média, 12 toneladas por dia. Isto corresponde a 8,8 km de caminhada, 133.332 golpes de facão, fazendo 36.630 flexões e giro no corpo, perdendo 8 litros de água por dia.

A contratação por terceirização, também regulamentada por lei e a ocorrência de migração dos trabalhadores, se justifica no setor pelo fato da colheita da cana-deaçúcar ser realizada por safras. Entretanto, esta forma de trabalho pode se resultar no aparecimento do desemprego e/ou subemprego sazonal.

Apesar das inúmeras regulamentações existentes, as fiscalizações ainda encontram situações degradantes de trabalho nas lavouras canavieiras. Em julho de 2018 a Superintendência Regional do Trabalho de Minas Gerais registrou em relatório fiscal a violação dos direitos trabalhistas, citando, por exemplo: falta de fornecimento de equipamentos de segurança, prorrogação irregular de jornada de trabalho no regime de $12 \mathrm{~h} \times 48 \mathrm{~h}$ sem autorização em clausula, ausência de concessão de períodos de descansos, entre outros (NOVACANA, 2018). 
Segundo a Repórter Brasil (2015) o trabalho forçado, a jornada exaustiva, condições degradantes e servidão por dívida, podem ser entendidos como trabalho semiescravo. Este fator é considerado como um crime a dignidade humana.

O estudo realizado por Scopinho et al (1999), explica que se de certa forma, a mecanização reduz os impactos de esforço físico que enfrentam os trabalhadores. Por outro lado, podem aumentar as pressões psicológicas, visto que a intensidade no ritmo de trabalho será maior. Além da avaliação de permanência do trabalho escravo, existe a necessidade do entendimento do perfil dos trabalhadores empregados na cana-de açúcar e o impacto que a mecanização exerce sobre este perfil.

De acordo com Moraes (2007b), a mecanização da colheita, terá como impacto em relação ao perfil dos ocupados uma criação de oportunidades para motoristas, técnicos em eletrônica, tratoristas, mecânicos, entre outros. Isto irá mudar o perfil do trabalhador, implicando necessidade de qualificação treinamento e alfabetização destas pessoas.

Por fim, cabe discutir o desemprego e as formas de realocação do fator trabalho. A utilização de máquinas na agricultura, vista no contexto do desenvolvimento da dinâmica capitalista pela busca de maior produtividade, é conhecida como Mecanização do campo. Entretanto, não se pode ignorar o fato de que além deste tipo de tecnologia, o progresso técnico incorpora o uso de tecnologias digitais em outros ramos da agricultura, fato que pode estar diretamente ligado a transformações da indústria 4.0 na qual, se tratando do cultivo da lavoura da cana, seria agricultura 4.0.

Conforme Junior e Saltorato (2018), a partir destas transformações pode-se destacar quatro impactos da indústria 4.0 na organização do trabalho. São eles: transformações nas relações socioprofissionais, necessidade de desenvolvimento de novas habilidades e competências no perfil dos empregados, maior interação entre o homem e a máquina e aumento do desemprego tecnológico, que se dá em contrapartida a mudança no perfil das pessoas empregadas, visto as novas exigências na qualificação por trabalhos mais complexos.

Além destas transformações citadas acima, caso o desemprego tecnológico se dê de forma intensiva, não há como negar o aprofundamento da precarização, 
fome e miséria no mercado de trabalho. Toda essa transformação tecnológica e seus impactos no mercado de trabalho é parte inerente do mundo capitalista, que busca sempre a inovação no anseio da competitividade e melhor uso dos recursos disponíveis.

$\mathrm{Na}$ próxima seção serão apresentados os impactos que a mecanização provocou no nível de emprego e as características principais do perfil dos trabalhadores paralelo às regiões brasileiras que foram constatadas como mais mecanizadas.

\section{EVOLUÇÃO DO NÍVEL DE EMPREGO E CARACTERÍSTICAS DOS TRABALHADORES}

Diante dos avanços tecnológicos da lógica capitalista, apresenta-se como as diferentes profissões referentes a lavoura da cana-de-açúcar são constantemente desafiadas a se adaptar ao capitalismo reinventado.

Para análise da evolução do emprego e principais características dos trabalhadores empregados na lavoura da cana-de-açúcar utilizou-se os dados extraídos da Pesquisa Nacional por Amostra de Domicílios (PNAD), para o período compreendido entre 2004 e 2008. Já para o período entre 2014 e 2018, utilizou-se a PNAD Contínua em sua forma anual, elaborada pelo Instituto Brasileiro de Geografia e Estatística (IBGE). Tal escolha se justifica devido aos cenários opostos do mercado de trabalho entre esses anos. No primeiro período, há um aquecimento do mercado de trabalho nacional com variação do Produto Interno Bruto anual acima de $3 \%$ em todos os anos. Já o segundo período apresenta o contrário: uma retração no nível de emprego e crescimento inferior a $1,1 \%$ e em alguns anos até mesmo apresentou-se crescimento negativo ${ }^{3}$. Com isso, busca-se evidenciar como o trabalho na lavoura da cana-de-açúcar foi afetado em períodos marcados por diferentes conjunturas econômicas e pela crescente incorporação da mecanização nesta atividade.

Analisa-se a partir desse ponto as características principais dos ocupados na lavoura da cana-de-açúcar. São elas: número de ocupados, sexo, escolaridade, cor

3 Dados disponíveis em: https://www.ibge.gov.br/estatisticas/economicas/contas-nacionais/9300contas-nacionais-trimestrais. html?=\&t=series-

historicas\&utm_source=landing\&utm_medium=explica\&utm_campaign=pib\%23evolucaotaxa\#tevolucao-taxa Acesso em: 05/08/2019. 
ou raça, faixa etária, rendimento, regiões, número de horas trabalhadas e, por fim, perfil técnico.

O número de ocupados na lavoura da cana-de-açúcar mudou significativamente nos dois períodos analisados. Conforme os Gráficos 3 e 4, percebe-se um aumento no número de ocupados no período entre 2004 e 2008, que pode ter acontecido pela própria geração de novos postos de trabalho no mercado de trabalho, influenciado pelo aquecimento da economia. Já no período entre 2014 e 2018, reduz-se consideravelmente o número de ocupados na atividade, chegando em 2018 ao número de 302.016 trabalhadores, representando uma queda de 58,49\% em 10 anos (comparando 2008 com 2018).

Gráfico 3 - Número de ocupados na lavoura da cana-de-açúcar. Brasil: 2004-2008.

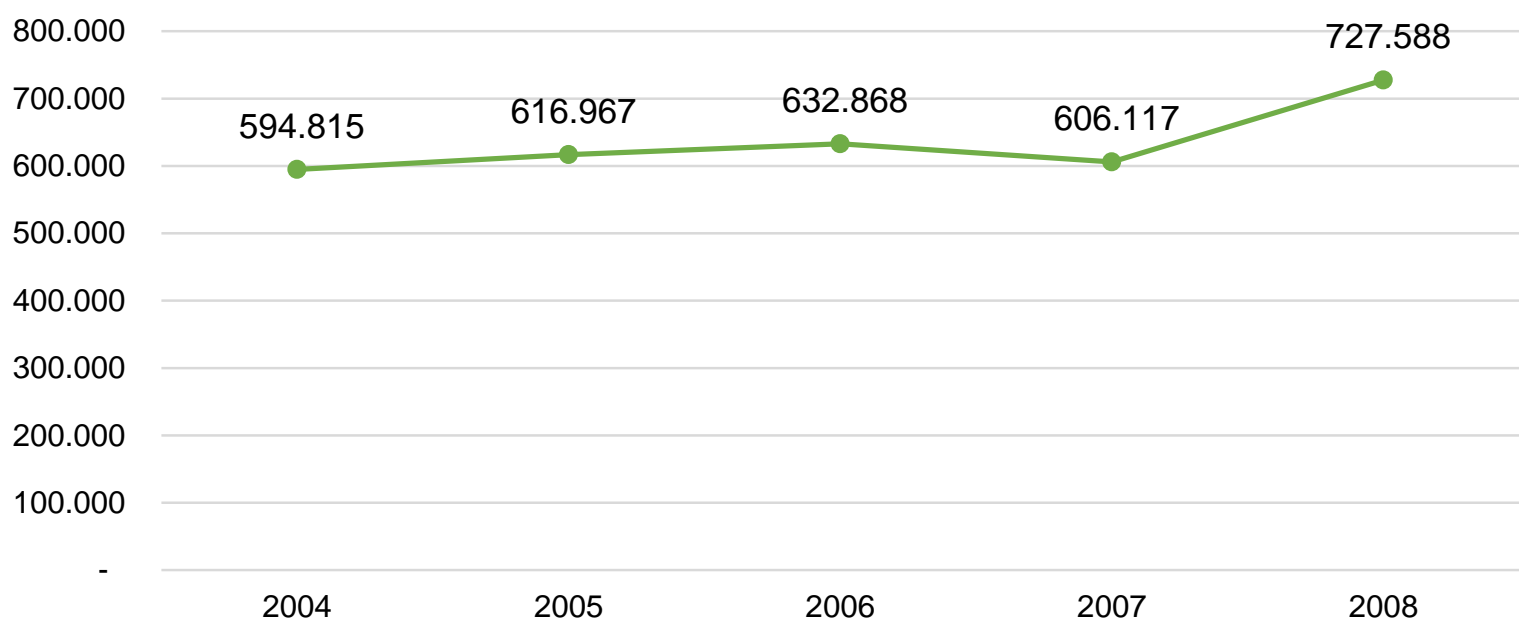

Fonte: Elaborado pelos autores com base nos dados das PNADs entre 2004 e 2008.

Gráfico 4 - Número de ocupados na lavoura da cana-de-açúcar. Brasil: 2014-2018.

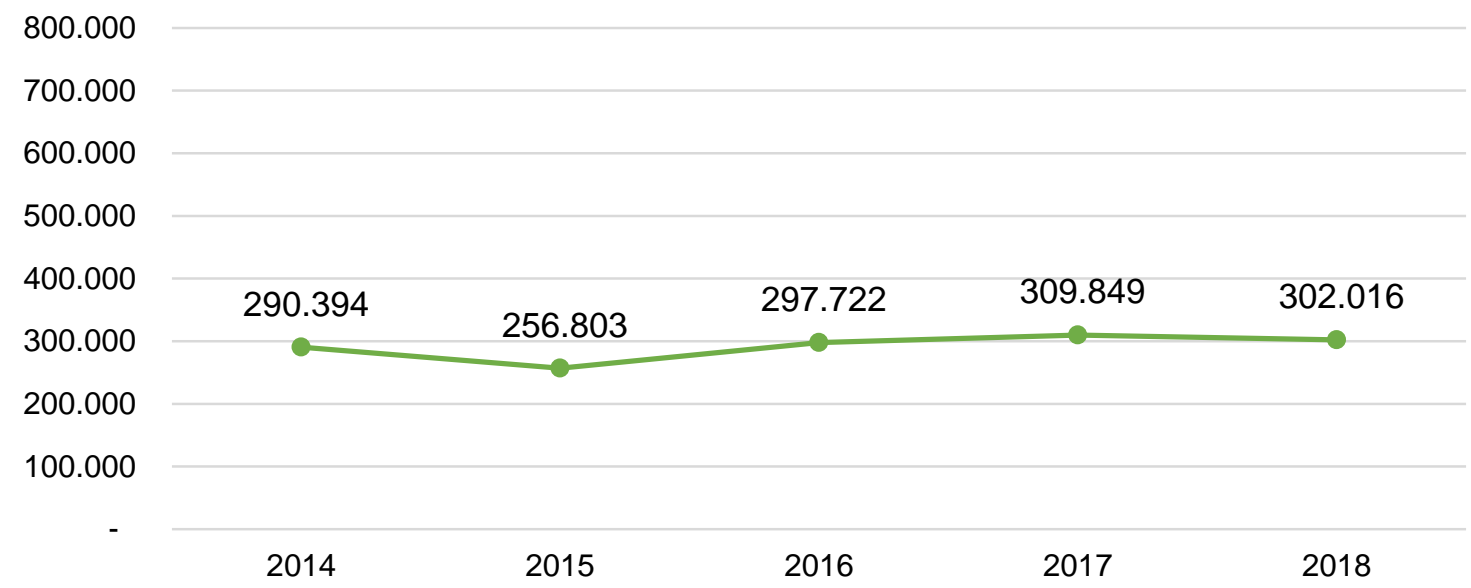

Fonte: Elaborado pelos autores com base nos dados das PNADs Contínuas entre 2014 e 2018. 
A redução do número de ocupados constatada no Gráfico 4 pode ter duas explicações: ser um resultado natural do baixo desempenho da economia após o ano de 2014 e/ou ser uma consequência e reflexo da mecanização cada vez mais intensa no agronegócio da cana. Porém, ressalta-se que a grande diminuição do número de ocupados representa um contingente significativo de pessoas trabalhando com a lavoura da cana. Por sua vez, espera-se que, para se manterem competitivas, as empresas envolvidas nesse ramo compensem a diminuição de trabalhadores, mas prezando por maior produtividade (que pode acontecer com a introdução de inovações tecnológicas nas colheitas e plantios).

Com a ciência de que houve uma redução significativa no número de ocupados na lavoura da cana, a partir de agora analisa-se a evolução do perfil desses trabalhadores. Essa análise auxilia a entender a própria dinâmica da cultura do açúcar e como ela se adapta a mudanças macroeconômicas - sejam elas nacionais ou internacionais.

Nos Gráficos 5 e 6, percebe-se que trabalhadores do sexo masculino sempre foram, majoritariamente, o grupo de trabalhadores na lavoura da cana. Entre 2004 e 2008 houve um aumento destas pessoas. Já entre 2014 e 2018, há pequenas variações ao longo dos anos, mas agora há menos homens na lavoura da cana se comparados ao período anterior.

Gráfico 5 - Evolução dos homens e das mulheres na condição de ocupados na lavoura da cana-deaçúcar. Brasil: 2004 - 2008.

\begin{tabular}{|c|c|c|c|c|c|}
\hline 700.000 & & & & & 653.408 \\
\hline 600.000 & & 541.088 & 567.829 & & \\
\hline 500.000 & 014.001 & & & 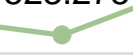 & \\
\hline 400.000 & & & & & \\
\hline 300.000 & & & & & \\
\hline 200.000 & & & & & \\
\hline 100000 & 80.434 & 75.879 & 65.039 & 82.842 & 74.180 \\
\hline- & 2004 & 2005 & 2006 & 2007 & 2008 \\
\hline & & - Mas & $\multimap-F e m$ & & \\
\hline
\end{tabular}

Fonte: Elaborado pelos autores com base nos dados das PNADs entre 2004 e 2008. 
Gráfico 6 - Evolução dos homens e das mulheres na condição de ocupados na lavoura da cana-deaçúcar. Brasil: 2014 - 2018.

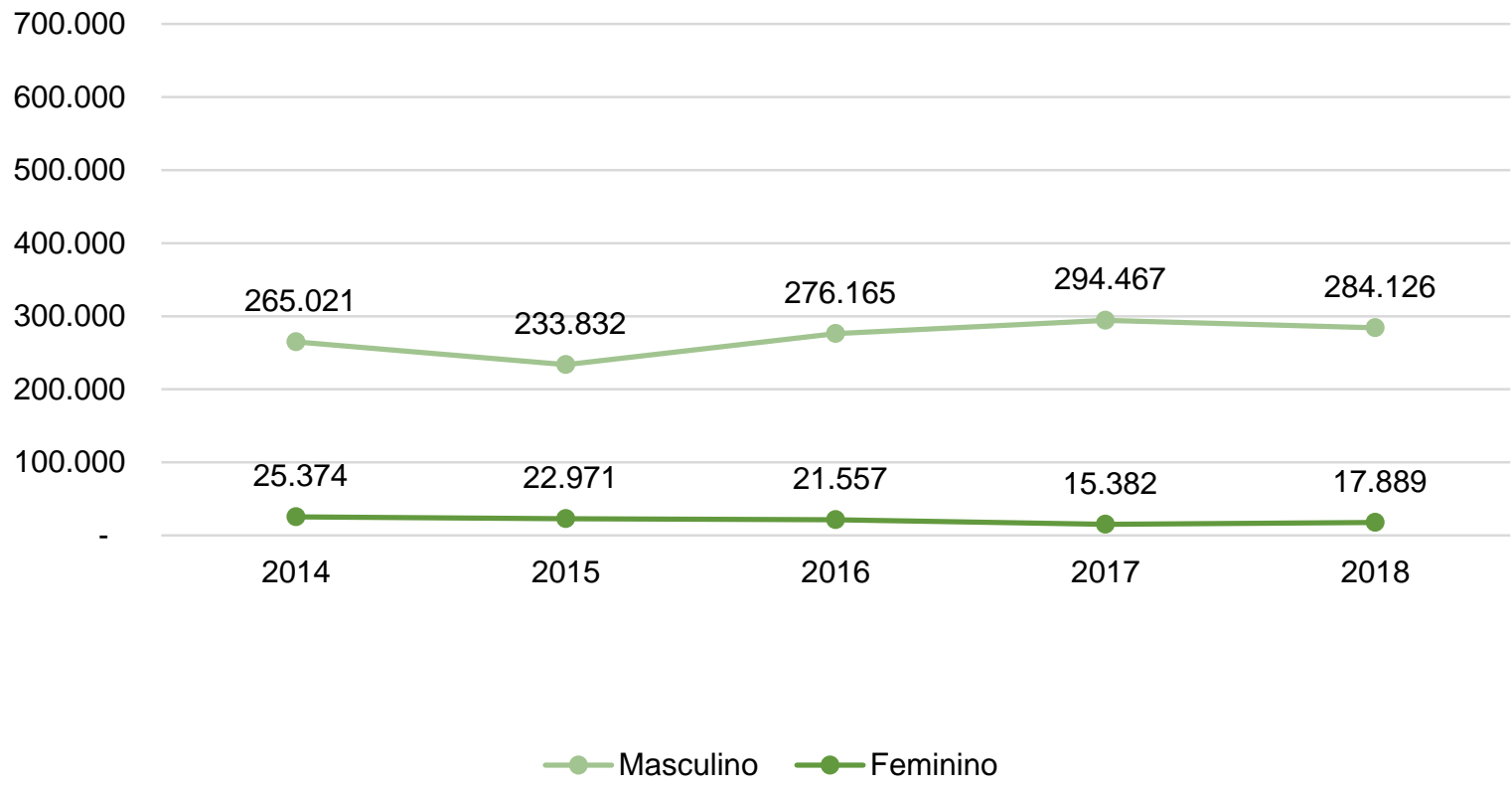

Fonte: Elaborado pelos autores com base nos dados das PNADs Contínuas entre 2014 e 2018.

Outro ponto relevante é que, proporcionalmente, as mulheres diminuíram sua participação no número de ocupados. Em 2008, homens representavam $90 \%$ do número de ocupados enquanto as mulheres representavam $10 \%$ do total. Já em 2018, as mulheres representavam apenas $6 \%$ do total de trabalhadores, ao passo que os homens aumentaram sua participação para 94\%. Nos dois períodos analisados, a participação feminina neste setor apresentou-se frequentemente baixa e estável.

Salienta-se agora a variação no perfil dos ocupados na lavoura da cana-deaçúcar quando se analisa a escolaridade dos trabalhadores que atuam nos canaviais. Pelos Gráficos 7 e 8, verifica-se que, entre 2004 e 2008, a maior parte desses profissionais ou eram analfabetos ou pessoas com menos de 1 ano de instrução, ou possuíam apenas o ensino fundamental. 
Gráfico 7 - Evolução da escolaridade dos trabalhadores da lavoura de cana-de-açúcar: Brasil: 20042008.

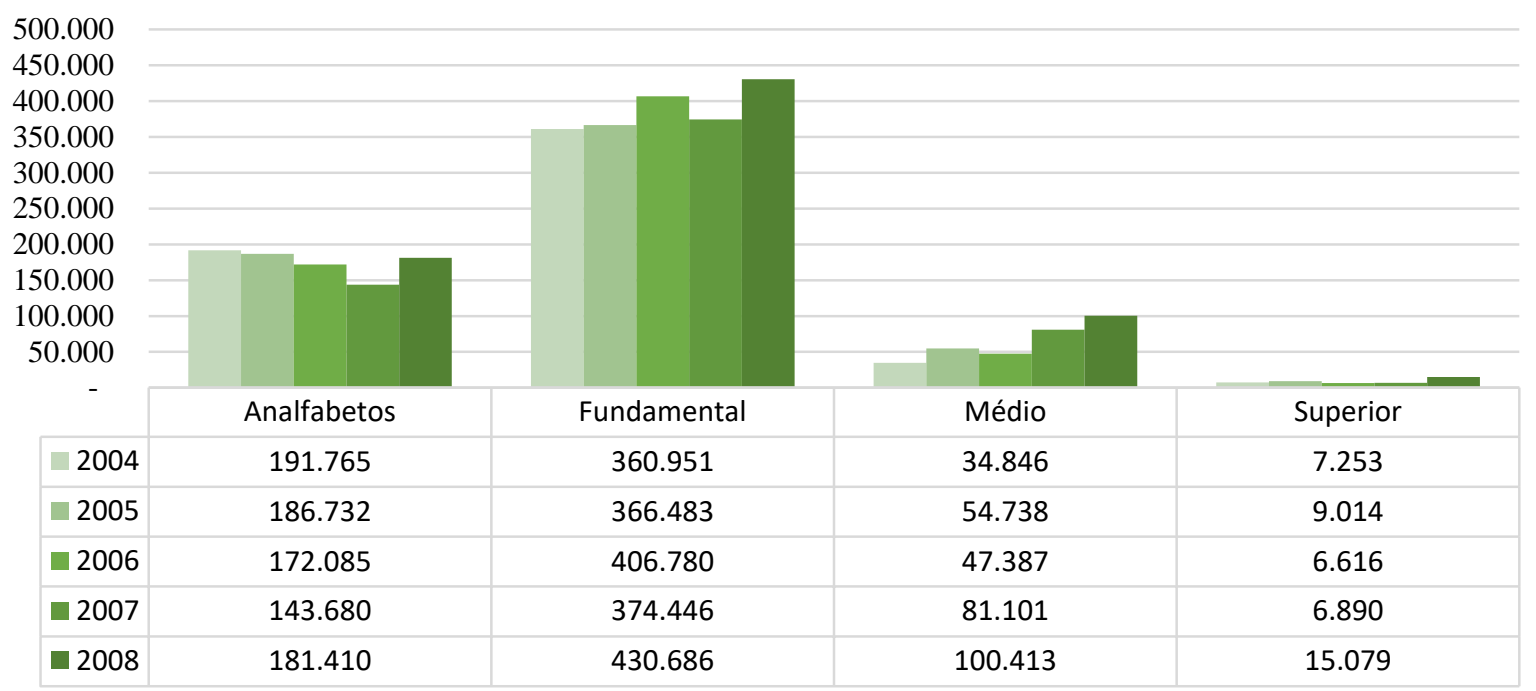

Fonte: Elaborado pelos autores com base nos dados das PNADs entre 2004 e 2008.

Em 2004, analfabetos ou pessoas com menos de 1 ano de instrução representavam $32 \%$ do total, enquanto os trabalhadores com ensino fundamental representavam $61 \%$ do total. Em 2008, esses valores se alteraram para $25 \%$ e $59 \%$, respectivamente. Em terceiro lugar, a porcentagem de trabalhadores que possuíam o ensino médio saltou de 6\% em 2004 para 14\% em 2008. Já os trabalhadores com ensino superior, mesmo apresentando uma pequena representatividade no total de pessoas ocupadas, mais que duplicaram, passando de 7.253 para 16.541 pessoas.

Por conseguinte, entre 2014 e 2018, percebe-se uma alteração significativa no perfil de escolaridade desses trabalhadores. Nesse período, empregados com ensino fundamental completo ou com ensino médio compunham o maior percentual do total de profissionais. Logo, houve um aumento de escolaridade nítido não só no setor da cana, mas em todo o Brasil.

Em 2018, trabalhadores com ensino médio completo representavam $1 / 4$ do total de ocupados. Já os trabalhadores com ensino fundamental representavam $58 \%$ desse número. Os analfabetos, que representavam 34\% em 2004, passaram a representar 12\% em 2018. Evidencia-se também o número de profissionais com ensino superior, que compunham 5\% do total de ocupados em 2018. 
Gráfico 8 - Evolução da escolaridade dos trabalhadores da lavoura de cana-de-açúcar: Brasil: 20142018.

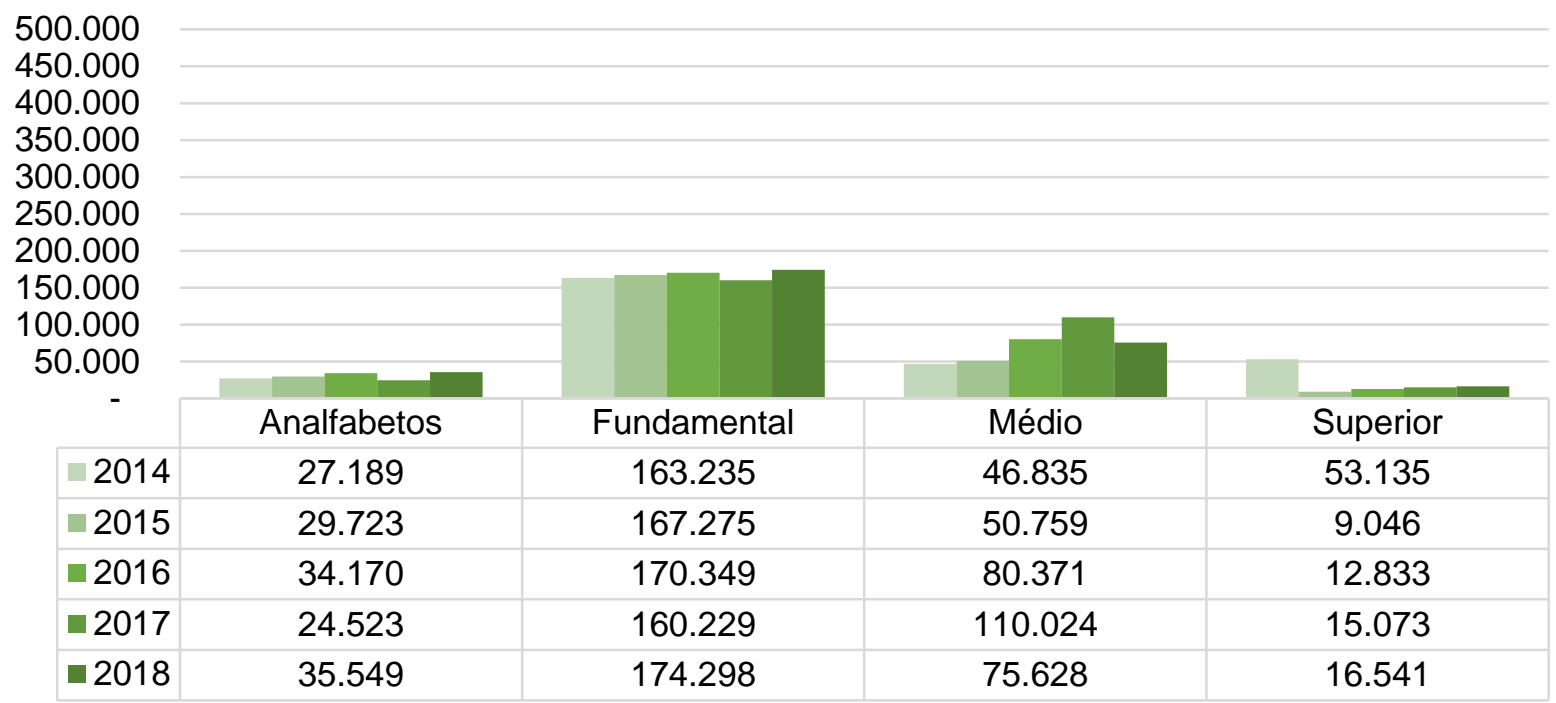

Fonte: Elaborado pelos autores com base nos dados das PNADs Contínuas entre 2014 e 2018.

Além das análises relacionadas ao trabalhador, como sexo e escolaridade, apresenta-se a seguir a cor/raça e a faixa etária nos Gráficos 9, 10, 11 e 12 . Pelo Gráfico 9 percebe-se que a maioria dos ocupados se autodeclaram brancos ou pardos. A proporção de trabalhadores autodeclarados pretos, amarelos ou indígenas não ultrapassa 11\%, no período entre 2004 e 2008. Já no período exposto no Gráfico 10, esta configuração não se altera. Há maior proporção de brancos e pardos no conjunto da população analisada e, aliado a isso, pretos, amarelos e indígenas ainda representam uma baixa porcentagem deste total.

Gráfico 9 - Cor ou raça dos ocupados na lavoura de cana-de-açúcar: Brasil: 2004-2008.

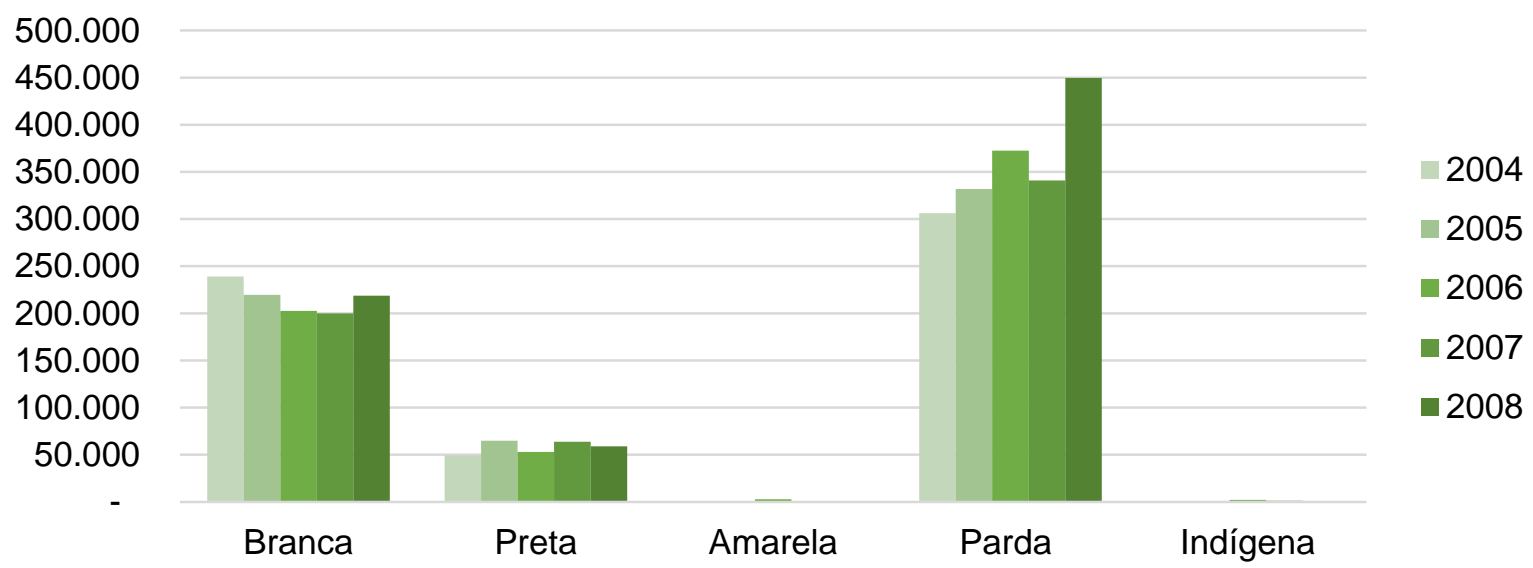

Fonte: Elaborado pelos autores com base nos dados das PNADs entre 2004 e 2008. 
Gráfico 10 - Cor ou raça dos ocupados na lavoura de cana-de-açúcar: Brasil: 2014-2018.

500.000

450.000

400.000

350.000

300.000

250.000

200.000

150.000

100.000

50.000

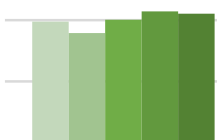

Branca

Preta

Amarela

Parda

Fonte: Elaborado pelos autores com base nos dados das PNADs Contínuas entre 2014 e 2018.

A faixa etária dos trabalhadores é representada, na maior parte, por 'adultos', que são, neste trabalho, considerados como indivíduos com idade entre vinte e cinco anos e sessenta anos de idade. Este grupo ocupa, em média, $76 \%$ do total dos ocupados ao longo de todo período analisado.

O percentual de jovens (considerados como pessoas com idade entre 14 e 25 anos) na composição total de ocupados, conforme apresentado nos Gráficos 11 e 12 , diminui consideravelmente, passando de $21 \%$ para $9 \%$, respectivamente, em 2008 e 2018.

A parcela de idosos (considerados neste trabalho como as pessoas com idade maior que sessenta anos) representou em todo período, em média, 5\% do total de ocupados e, mesmo sendo um número não tão significativo, se apresenta como preocupante, visto que o trabalho na lavoura da cana-de-açúcar é desgastante e exige grande esforço físico. 
Gráfico 11 - Faixa etária dos trabalhadores na lavoura de cana-de-açúcar: Brasil: 2004-2008.

600.000

500.000

400.000

300.000

200.000

100.000

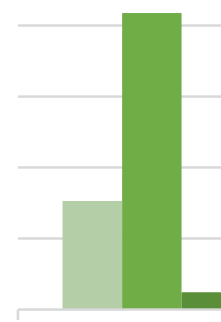

2004

Jovens $\square$ Adultos $\square$ Idosos

Fonte: Elaborado pelos autores com base nos dados das PNADs entre 2004 e 2008.

Gráfico 12 - Faixa etária dos trabalhadores na lavoura de cana-de-açúcar: Brasil: 2014-2018.

800.000

700.000

600.000

500.000

400.000

300.000

200.000

100.000

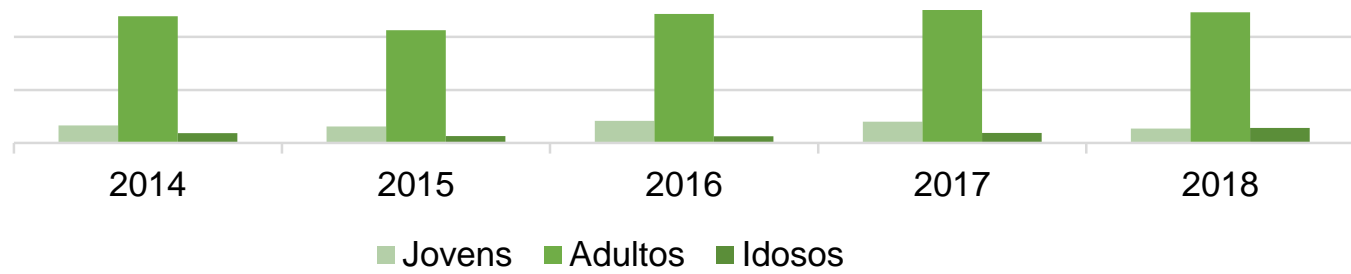

Fonte: Elaborado pelos autores com base nos dados das PNADs Contínuas entre 2014 e 2018.

Para analisar a evolução do rendimento dos trabalhadores nas lavouras da cana-de-açúcar, utilizou-se o salário médio bruto de toda a população ocupada em cada ano, considerando 2004 como o ano-base para deflacionar e estimar a variação do salário real entre os dois períodos.

No período exposto no Gráfico 13, a variação do rendimento médio bruto mensal real foi de $61 \%$. No mesmo espaço de tempo, o salário mínimo real vigente aumentou $57 \%$, ou seja, o rendimento na lavoura da cana-de-açúcar teve um aumento levemente superior ao rendimento dos trabalhadores que ganhavam um salário mínimo. 
No período entre 2014 e 2018 (apresentado no gráfico 14) o rendimento médio bruto mensal real dos trabalhadores, considerando o ano-base em 2004, obteve um aumento de $33 \%$ que, quando comparado ao aumento do salário mínimo real (28\%), se mostrou ligeiramente mais elevado.

Conforme Liboni e Júnior (2008), as mudanças provocadas no mercado de trabalho pela mecanização, por meio de uma mudança no nível de escolaridade, podem contribuir para o aumento da remuneração dos trabalhadores. Ou seja, nos dois períodos analisados neste trabalho, verificou-se um aumento no rendimento real médio dos profissionais envolvidos com a lavoura da cana-de-açúcar e isso pode ter ocorrido devido à crescente mecanização a que tal colheita vem sendo acometida.

Gráfico 13 - Evolução do Rendimento Médio Bruto Mensal Real dos trabalhadores da lavoura da cana-de-açúcar em $\mathrm{R} \$$ (2004=100). Brasil 2004-2008.

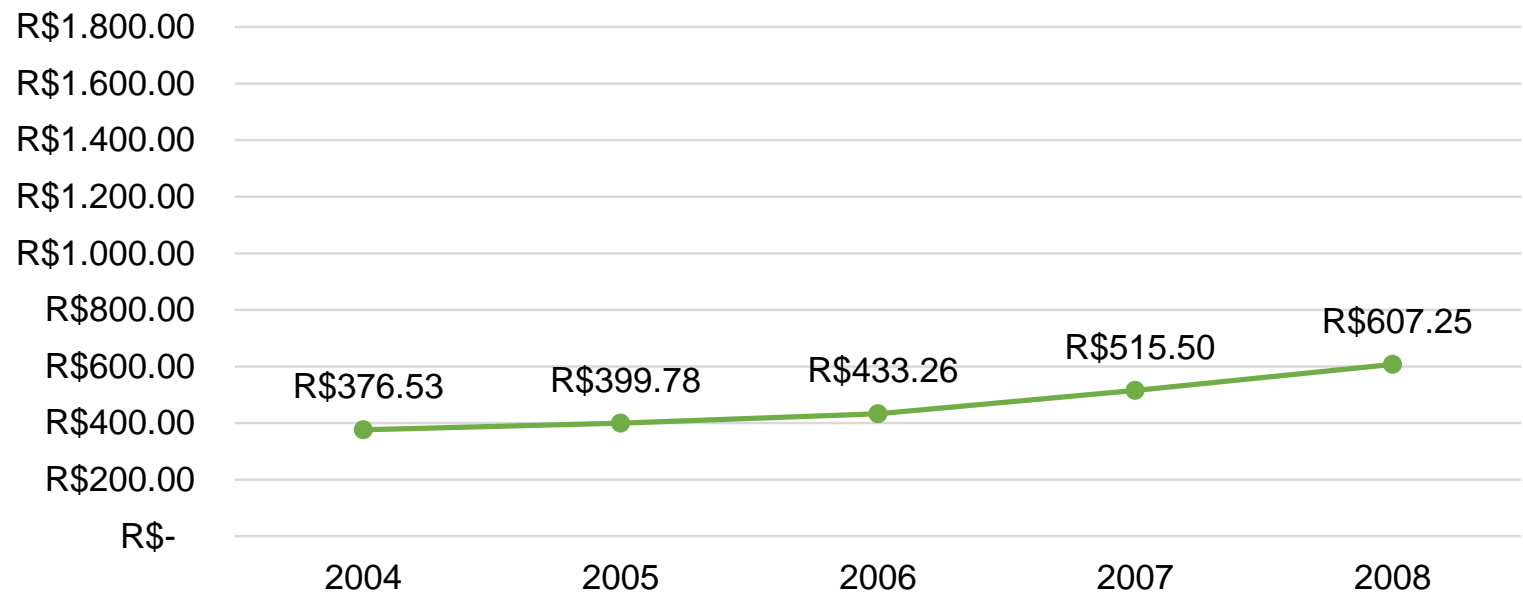

Fonte: Elaborado pelos autores com base nos dados das PNADs entre 2004 e 2008.

Gráfico 14 - Evolução do Rendimento Médio Bruto Mensal Real dos trabalhadores da lavoura da cana-de-açúcar em R \$ (2004=100). Brasil 2014-2018.

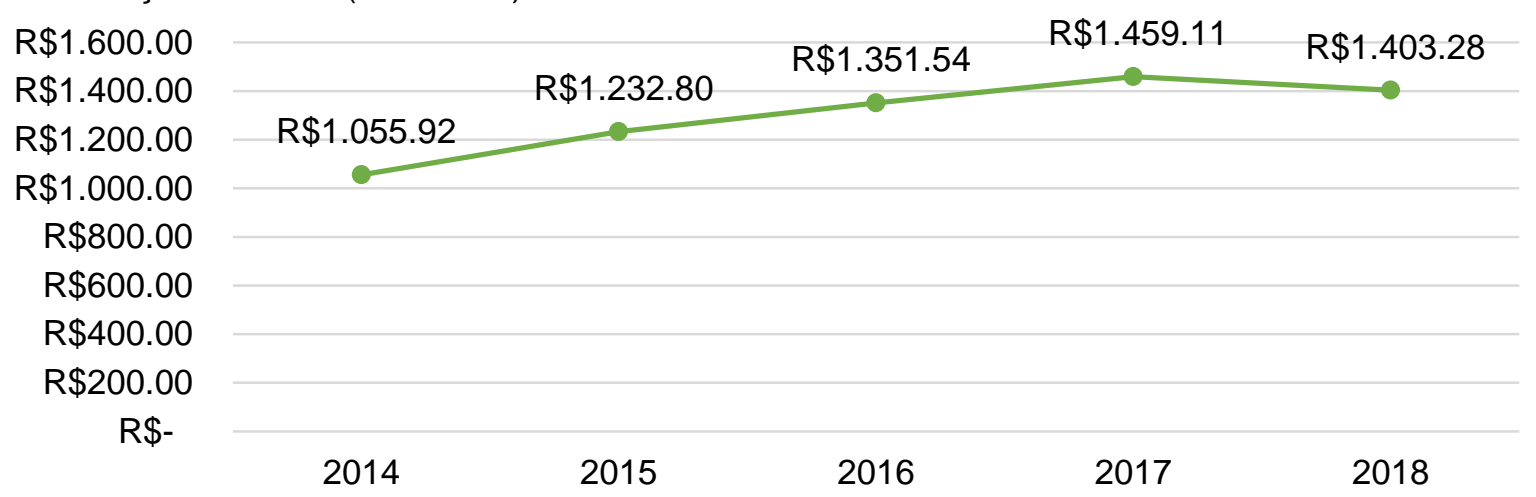

Fonte: Elaborado pelos autores com base nos dados das PNADs Contínuas entre 2014 e 2018. 
Agora, analisa-se como o número de ocupados está distribuído entre as regiões do Brasil. Cada região possui um percentual de mecanização diferente e isso pode influenciar na variação do número de ocupados ao longo dos anos. Conforme eleva-se o grau de mecanização em uma região, pode ser que o número de ocupados se reduza. A análise das regiões foi feita separadamente entre dois grupos: grande região Norte/Nordeste e grande região Centro-Sul.

Do total de pessoas ocupados entre o período de 2004 a 2008, como demonstrado no gráfico 15 , a maioria das pessoas ocupadas estavam concentradas na grande região Norte/Nordeste que, de acordo com o gráfico 1, mostrou ser a região menos mecanizada. Porém, vale considerar que há uma particularidade em relação à região Norte.

Enquanto a região Nordeste aparece como a com menor grau de mecanização, a região Norte aparece com o maior percentual de mecanização. Mas, a junção destas duas regiões faz com que a grande região Norte-Nordeste apareça como a grande região menos mecanizada se comparada à grande região CentroSul.

Ao longo do tempo, a região Norte alcançou $100 \%$ de mecanização na safra 2018/19. Simultaneamente a isso, o número de pessoas ocupadas nessa região passou de 12.990 pessoas em 2004 para 2.973 pessoas em 2018. Pode ser que essa redução significativa no número de ocupado seja justificado pela total mecanização da colheita da cana nessa região.

Analisando agora apenas o período entre 2014 e 2018, demonstrado no gráfico 16, a grande região que concentra o maior número de pessoas ocupadas na lavoura da cana passa a ser a Centro-Sul, sendo a mais mecanizada. Aqui, entra-se em uma contradição, pois a grande região com maior número de ocupados coincidiu com a grande região mais mecanizada. Contudo, vale observar a particularidade de cada Estado. Dentre os Estados que compõem essa grande região, os que possuem maior grau de mecanização são: Minas Gerais, Mato Grosso do Sul e São Paulo, com $99,5 \%, 99,1 \%$ e $95,9 \%$ na safra $2017 / 18$, respectivamente. Entretanto esses percentuais eram $37,5 \%, 34,3 \%$ e $33 \%$, para cada Estado mencionado anteriormente, na safra de 2007/08, evidenciando então um salto expressivo no percentual de mecanização da colheita da cana-de-açúcar nessas localidades. 
O número de ocupados caiu 31\% em Minas Gerais e 49\% em São Paulo, se comparando os dados entre 2004 e 2018. Já Mato Grosso do Sul mais do que quadruplicou nesse período. Pelos dados acima, salienta-se que apesar da grande região Centro-Sul como um todo ter aumentado o seu número de ocupados e ser a mais mecanizada, quando se analisa apenas os Estados mais mecanizados, observa-se que de fato o número de ocupados se reduziu.

Gráfico 15 - Número de ocupados por grande região na lavoura da cana-de-açúcar. Brasil: 20042008.

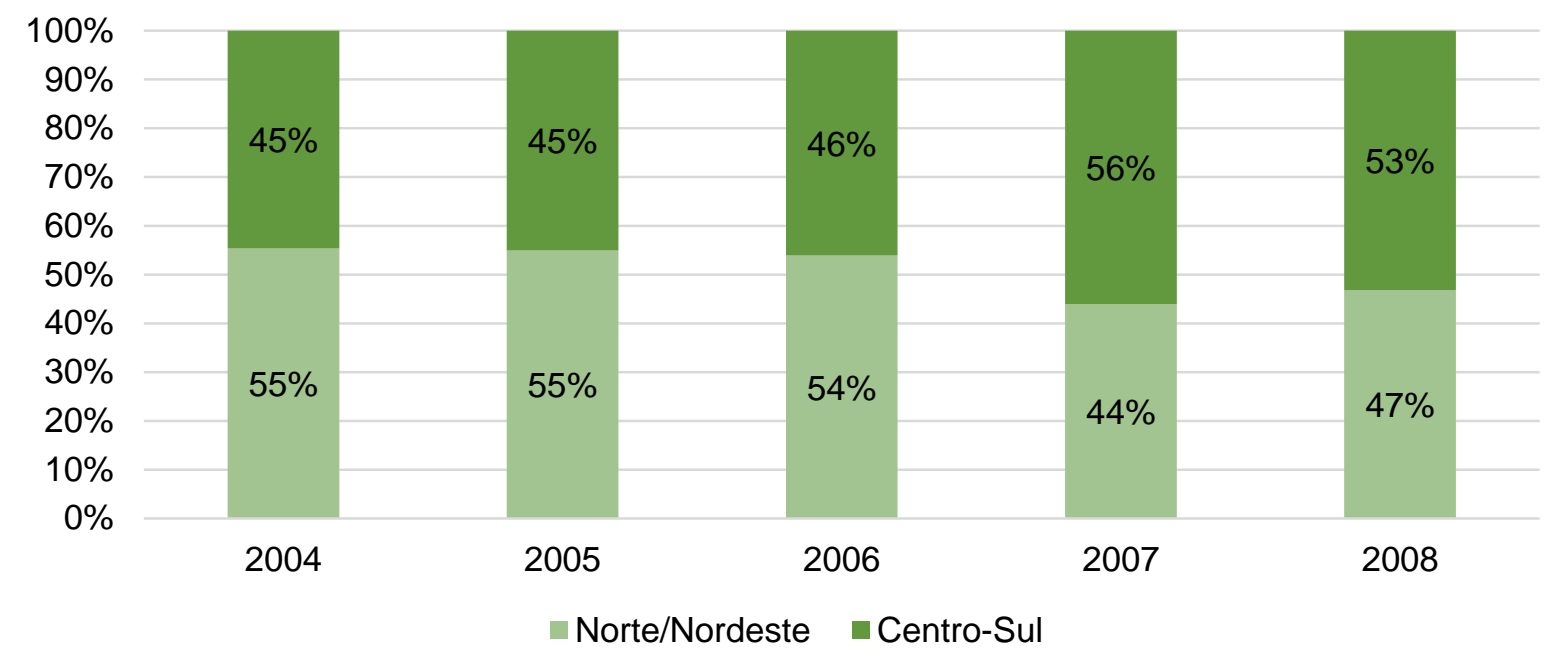

Fonte: Elaborado pelos autores com base nos dados das PNADs entre 2004 e 2008.

Gráfico 16 - Número de ocupados por grande região na lavoura da cana-de-açúcar. Brasil: 20142018.

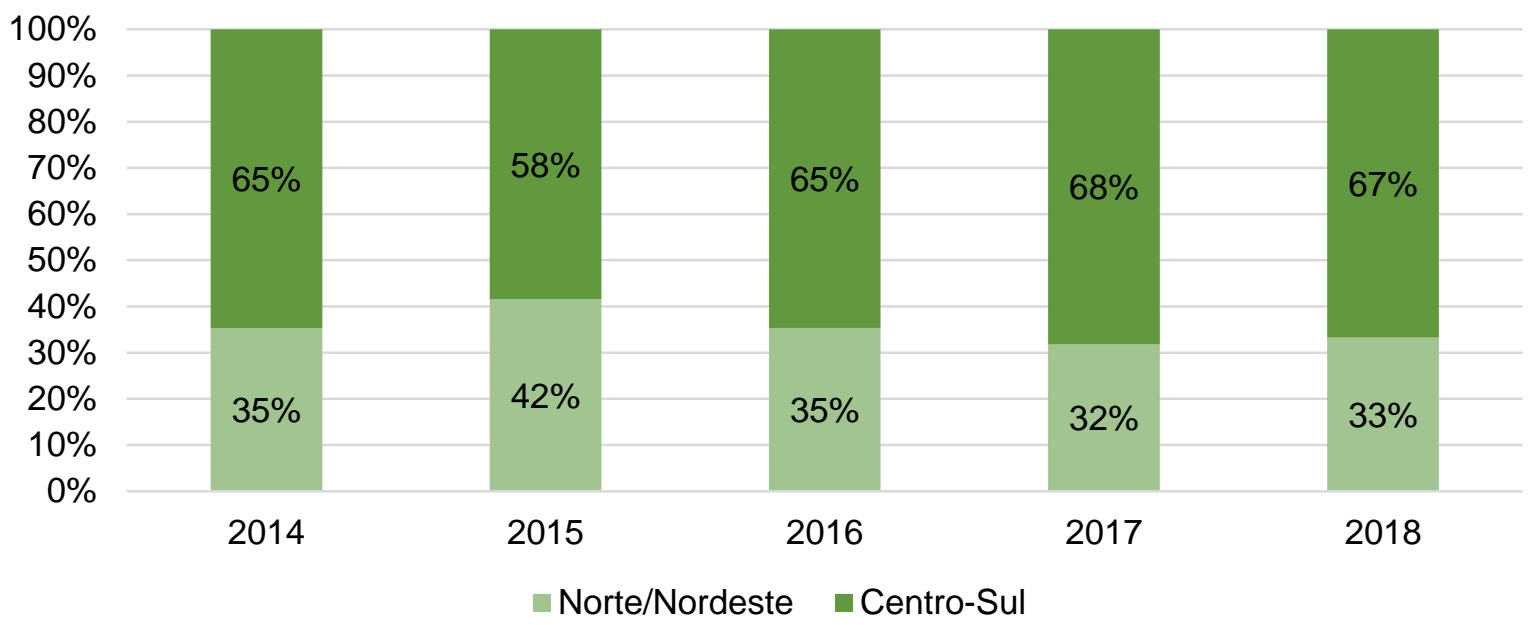

Fonte: Elaborado pelos autores com base nos dados das PNADs Contínuas entre 2014 e 2018. 
Examinando o número de horas trabalhadas ao longo dos dois períodos, verifica-se que esse valor geralmente se encontrou na faixa entre $40 \mathrm{~h}$ a $48 \mathrm{hs}$. Observa-se ainda um percentual considerável de pessoas que trabalharam $49 \mathrm{hs}$ ou mais na lavoura. Esse número era, em média, 24\% em 2004 e depois passou para $13 \%$ em 2018. Apesar da redução, ainda assim o número é relevante, pois nota-se que houve muitos trabalhadores com uma carga horária de trabalho extensa, o que consiste em uma irregularidade no mercado de trabalho. $O$ pagamento por produtividade, prática comum nas lavouras da cana-de-açúcar, pode influenciar na decisão em manter essa alta carga de trabalho.

Investigando o percentual de trabalhadores na cana-de-açúcar que possuíam um vínculo empregatício formal de trabalho, no período entre 2014 e 2018, verificase que, em média, $77 \%$ desses trabalhadores possuíam carteira assinada. Os $23 \%$ restantes não possuíam carteira assinada, pois o vínculo empregatício estabelecido era diferente do regido pela Consolidação das Leis do Trabalho (CLT). O fato de $23 \%$ dos trabalhadores não serem abrangidos pelo emprego formal pode contribuir para o aumento de irregularidades trabalhistas, porque fatos como excesso de jornada de trabalho, ausência de períodos de descanso regulares e fiscalização inadequada de direitos mínimos dos trabalhadores podem contribuir para tornar ainda mais precária as condições de trabalho na lavoura da cana-de-açúcar.

Em relação a mudança no perfil técnico, busca-se evidenciar se houve aumento no número de postos de trabalho que exigem maior qualificação e redução dos trabalhadores com menor qualificação, como, por exemplo, colhedores, cortadores e carregadores etc. Porém, quando se analisa ambos os períodos estudados neste trabalho, verifica-se que ocorreram mudanças na classificação de ocupações estabelecida pela PNAD. Nos anos anteriores a 2012 existia um detalhamento das profissões, mas após este mesmo ano, o IBGE realizou uma nova alocação destas, que foi o caso dos trabalhadores elementares da lavoura da canade-açúcar.

Sendo assim, para avaliação de mudança no perfil, optou-se por considerar a evolução das profissões apenas no período compreendido entre os anos de $2014 \mathrm{e}$ 2018, por ser o período que constata maior mecanização nas lavouras da cana - de 
acordo com o período analisado neste trabalho - visto que a evolução da mesma é crescente.

Para tanto utilizou-se a seguinte metodologia: a partir dos dados de pessoas ocupadas em atividades relacionadas ao cultivo da cana-de-açúcar concentrados na PNAD, isto é, através do código 01105 - da Classificação Nacional de Atividades Econômicas Domiciliar 2.0 - filtrou-se apenas as profissões em que se enquadram as pessoas com cargos que requerem algum grau de qualificação, ou seja, técnicos agropecuários, mecânicos, reparadores, ajustadores, condutores e operadores de veículos a motor, máquinas agrícolas, caminhões, ônibus e também os cargos elementares relacionados ao cultivo da cana.

O Gráfico 17 exibe a evolução de dois agrupamentos de trabalhadores, sendo eles: trabalhadores com maior qualificação e trabalhadores elementares. O primeiro grupo é composto por técnicos agropecuários, agricultores e trabalhadores qualificados, mecânicos, operadores, condutores de máquinas, caminhões e outros; já o segundo grupo é definido por trabalhadores elementares da agricultura e carregadores.

Observa-se que apesar do número de trabalhadores elementares se manter constante, o número de trabalhadores com qualificação aumentou, o que pode ser justificado pela mudança no perfil dos postos de trabalho. Este comportamento poderá se manter nos próximos anos, pelo fato de que a completa mecanização não ocorrerá de maneira simultânea em todos os estados. Além disso, a mecanização completa em todos os canaviais brasileiros é tecnicamente inviável com a atual tecnologia disponível, pois ainda há terrenos em que as máquinas não conseguem adentrar para realizar o corte mecânico (Abreu et al, 2009).

De acordo com (Torquato, 2013), a partir da análise de exclusão líquida de trabalhadores, pode-se estimar que a redução de pessoas empregadas na colheita da cana é de cinquenta e dois postos de trabalho para cada máquina acrescentada na etapa da colheita. Isto porque, conforme estimado pelo autor, um trabalhador consegue cortar, em média, 8,67 toneladas de cana por dia, enquanto uma máquina colhedora consegue alcançar 549,7 toneladas fazendo a mesma função.

O Gráfico 17 apresenta um aumento no número de postos de trabalhos considerados qualificados e, portanto, corrobora com o fato de que, na medida em que a mecanização se torna cada vez maior nas plantações da cana-de-açúcar, há 
uma redução de postos de trabalho com tarefas básicas ou elementares necessários para manter a produtividade de tal atividade.

Gráfico 17 - Evolução do trabalho qualificado em comparação com o trabalho elementar nas lavouras da cana-de-açúcar. Brasil: 2014-2018.

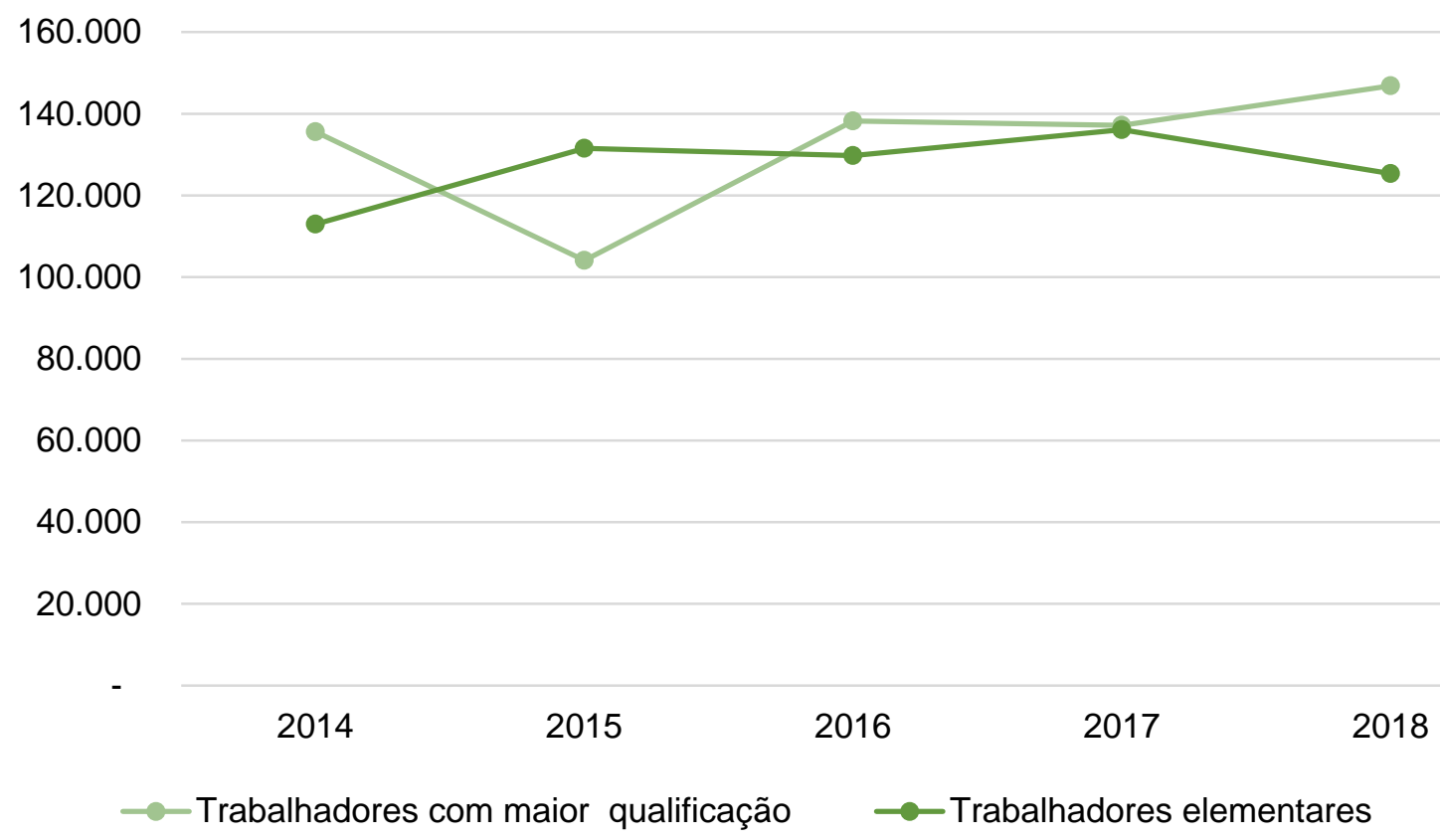

Fonte: Elaborado pelos autores com base nos dados das PNADs Contínuas entre 2014 e 2018.

O impacto da mecanização é mais evidente na fase da colheita da cana-deaçúcar, conforme Abreu et al (2009). Isso significa que postos de trabalhos elementares são os mais suscetíveis ao desemprego, pois entre o número de trabalhadores elementares, a função de colhedor/cortador é a mais expressiva.

Apesar da redução dos postos de trabalho que exigem menos qualificação por parte dos profissionais que atuam nas lavouras, salienta-se que podem haver melhorias na promoção da alfabetização dessas pessoas, caso haja incentivo para que essa mão de obra se torne qualificada e almeje novos postos de trabalho com maior qualificação e remuneração (Torquato, 2013).

Evidencia-se que 0 aumento de postos de trabalhos que exigem maior qualificação não é em proporção adequada para compensar a menor utilização de trabalhos considerados elementares na lavoura da cana-de-açúcar - decorrente dessa mecanização crescente - com perdas significativas de postos de trabalho. Entretanto, leva-se em consideração os benefícios que podem ser conquistados 
para a saúde dos trabalhadores e para o meio ambiente (Ramos, 2007). Ou seja, há um dilema evidente entre melhorias ambientais e na saúde dos trabalhadores, mas com mais pessoas desempregadas e postos de trabalho definitivamente excluídos.

Por fim, acrescenta-se que a mecanização é um processo que está cada vez mais presente na atividade da cana. Seus impactos no mercado de trabalho e as consequências sociais nas novas funções a serem desempenhadas pelos trabalhadores são inevitáveis e inerentes à busca incessante por produtividade e competitividade das atividades agrícolas.

\section{CONSIDERAÇÕES FINAIS}

Dos diversos tipos e formas em que se desenvolve o progresso técnico na dinâmica capitalista, a mecanização imposta no setor da agricultura surge como maneira de garantir a competitividade das grandes empresas e no setor produtor da cana-de-açúcar não é diferente. Este produto, que explica parte da colonização do país, é uma das principais mercadorias quando se trata da parcela de mercado no contexto mundial e também um dos setores que contém grande número de trabalhadores ocupados.

No contexto da mecanização da lavoura da cana-de-açúcar, a sua evolução e interligação com os temas ambientais e impactos no mercado de trabalho, aparecem como temas que se inserem na discussão das relações socioeconômicas. $\mathrm{Na}$ origem deste tema surgem dois aspectos principais: a busca pelo aumento da produtividade e redução de custos e a solução para a poluição gerada pela queima da palha da cana na lavoura.

No primeiro aspecto busca-se resolver as questões empresariais da dinâmica capitalista que, conforme o aumento da concorrência, a implementação da mecanização aparece como solução viável para alcançar o maior nível de colheita com otimização de tempo e custos. Já no contexto interligado ao meio ambiente, conforme estabelecido por lei, a queimada da palha da cana-de-açúcar tem tempo estabelecido para o fim e deverá ser reduzido gradativamente no intuito de preservação ambiental.

Diante destes aspectos inicias, o presente trabalho buscou avaliar como a mecanização impacta no mercado de trabalho da cana no Brasil, mostrando como 
se dá evolução do emprego em dois períodos distintos e quais são as principais características dos trabalhadores empregados na lavoura da cana-de-açúcar.

O primeiro período está compreendido entre os anos de 2004 a 2008 e o segundo período entre 2014 e 2018. A escolha dos mesmos se justifica pelo fato dos diferentes momentos vivenciados pela economia brasileira. Enquanto no primeiro período o mercado de trabalho apareceu de forma dinâmica e a economia com expansão, no segundo período observou-se que uma retração da demanda, o que teve grande impacto no mercado de trabalho. Sendo assim, avaliou-se se o número de trabalhadores teve comportamentos distintos nos dois períodos e como a mecanização afetou as pessoas ocupadas. Além disso, avaliou-se as principais características dos trabalhadores empregados como: número de ocupados, sexo, escolaridade, cor ou raça, faixa etária, rendimento, regiões, número de horas trabalhadas e, por fim, os cargos ocupados.

Em relação ao emprego no primeiro período analisado (2004-2008) observouse que o número de ocupados teve uma linha de tendência positiva e se deu, em média, 636.000 trabalhadores. Entretanto houve uma queda de 58,49\% destas mesmas pessoas em 10 anos (comparando 2008 com 2018), o que pode ser explicado simultaneamente por dois motivos: a retração da atividade econômica no país e o aumento da mecanização que impacta na redução do número de trabalhadores na lavoura.

Quando se avalia o perfil das pessoas ocupadas, observou-se que a prevalência do sexo masculino, majoritariamente, nos dois períodos, sendo que o número de pessoas do sexo feminino se apresentou baixo e estável. A raça está concentrada nas cores branca e parda. Quanto à faixa etária há predominância de pessoas adultas com idade entre vinte e cinco e sessenta anos, estando o número de horas trabalhadas compreendido, em sua maioria, entre 40 a 48 horas.

A escolaridade das pessoas apresentou uma leve modificação nos dois períodos, sendo que entre 2004 e 2008 a maioria apresentava um nível de instrução em analfabetos e ensino médio. Já entre 2014 e 2018, houve queda do número de ocupados dos analfabetos e ensino fundamental, enquanto o nível médio e superior se elevou. Este fato pode ser justificado pela mudança de perfil exigida pelos novos postos de trabalho surgidos após o aumento da mecanização. 
O rendimento médio dos trabalhadores apresentou ganho real nos dois períodos, sendo que no primeiro período teve um ganho real de $61 \%$ e no segundo período um ganho real de $33 \%$. Este fato pode ser justificado pela valorização real do salário mínimo nos períodos analisados e também pela mudança de perfil, visto que conforme a mecanização muda os cargos dos trabalhadores, a remuneração poderá aumentar.

Em relação as regiões brasileiras, evidenciou-se que a região Norte está 100\% mecanizada coincidindo com o menor número de ocupados. Além disso, a grande região Centro/Sul, apesar de possuir o maior número de ocupados e ser simultaneamente a mais mecanizada quando comparada à grande região Norte/Nordeste, se separados os estados de Minas Gerais e São Paulo, observa-se uma queda no número de ocupados, quando a mecanização ultrapassa os $90 \%$.

Por fim, cabe observar que quando se analisa a evolução do trabalho qualificado em comparação com o trabalho elementar nas lavouras da cana-deaçúcar, o primeiro mostrou-se crescente, enquanto o segundo apresentou leves variações no período de 2014 a 2018, o que mostra que, de fato, a mecanização pode provocar além de uma mudança no perfil técnico dos trabalhadores, uma gradativa redução no número de pessoas ocupadas.

Devido a dificuldades e limitações dos dados utilizados neste trabalho, buscou-se avaliar como se deu a evolução da mecanização da cana-de-açúcar e as consequências no mercado de trabalho deste setor. Para estudos posteriores da mecanização, pode-se avaliar de maneira mais significativa qual o real impacto desta na lavoura da cana, com análises econométricas, na tentativa de evidenciar como a introdução do progresso técnico trouxe mudanças no mercado de trabalho deste tipo de atividade.

\section{REFERÊNCIAS}

ABREU, Dirce et al. Impacto social da mecanização da colheita de cana-de-açúcar. Revista Brasileira Medicina do Trabalho. v.4, 5 e 6, p. 1-11, São Paulo, jul. de 2009. Disponível em:

<http://www.anamt.org.br/site/upload_arquivos/revista_brasileira_de_medicina_do_tr abalho_-_volumes_4,5_e_6_20122013145546533424.pdf> Acesso em: 05 ago. 2019. 
ALMEIDA, Jalcione. Da ideologia do progresso à ideia de desenvolvimento (rural) sustentável. 1995.

BARBOSA, A.. O Mercado De Trabalho: Uma Perspectiva De Longa

Duração. Estudos Avançados, 30(87), 7-28. 2016. Disponível em: < http://www.revistas.usp.br/eav/article/view/119112>. Acesso em 28 jul. 2019.

BELLUZZO, Luiz Gonzaga; MAZZUCCHELLI, Frederico. Ensaios sobre o capitalismo no século XX. Scielo-Editora UNESP, 2004. Disponível em: $<$ https://books.google.com.br/books?hl=pt-

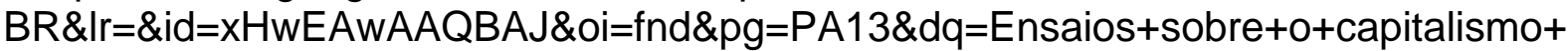
no+s\%C3\%A9culo+XX\&ots=2XJ7D0SUTV\&sig=vrWwKcZaeqCAZZGKj5GnTlilLDI> Acesso em: 28 jul. 2019.

BRASIL. Companhia Nacional de Abastecimento. Acompanhamento da safra brasileira: cana-de-açúcar, v. 6 - Safra 2019/20, n. 1 - Primeiro levantamento, Brasília, p. 1-58, maio de 2019a. Disponível em: <https://www.conab.gov.br/infoagro/safras/cana>. Acesso em: 01 jul. 2019.

BRASIL. Companhia Nacional de Abastecimento. Boletim da safra de cana-deaçúcar. Tabela de levantamento, Brasília, maio de 2019b. Disponível em: <https://www.conab.gov.br/info-agro/safras/cana>. Acesso em: 01 jul. 2019.

COSTA, Achyles Barcelos de. O desenvolvimento econômico na visão de Joseph Schumpeter. Caderno Instituto Humanitas Unisinos, ano, v. 4, 2006. Disponível em: <

http://www.ihu.unisinos.br/images/stories/cadernos/ideias/047cadernosihuideias.pdf> Acesso em: 28 jul. 2019.

FURTADO, Celso. Formação econômica do Brasil. 32 ed. São Paulo: Companhia Editora Nacional, 2003.

JUNIOR, Geraldo Tessarini; SALTORATO; Patrícia. Impactos da Industria 4.0 na organização do trabalho: uma revisão sistemática de literatura. 2018.

JUNIOR, Rudinei Toneto; LIBONI, Lara Bartocci. Evolução recente do mercado de trabalho da cana-de-açúcar no brasil (1995-2006). Organizações Rurais \& Agroindustriais, v. 10, n. 3, p. 455-474, 2008. Disponível em: $<$ https://www.redalyc.org/pdf/878/87812765010.pdf> Acesso em: 05 ago. 2008.

KREIN, D.; GIMENEZ, Denis Maracci; SANTOS, Anselmo Luis dos. Dimensões críticas da reforma trabalhista no Brasil. Campinas: Curt Nimuendajú, 2018. Disponível em: < https://www.eco.unicamp.br/images/arquivos/LIVRODimensoesCriticas-da-Reforma-Trabalhista-no-Brasil.pdf >. Acesso em: 07 ago. 2019.

LIMA, Débora Juliene Pereira. A dinâmica da cana-de-açúcar no Brasil - 2002 a 2012. Tese de Doutorado, Universidade Federal de Uberlândia, 2016. Disponível em: < https://repositorio.ufu.br/handle/123456789/5164/simplesearch?filterquery=Lima\%2C+D\%C3\%A9bora+Juliene+Pereira\&filtername=author\&fi Itertype=equals $>$ Acesso em: 04 ago. 2019.

LIMA, Débora Juliene Pereira. Agroindústria canavieira e emprego: evolução recente e perspectivas. Dissertação de Mestrado. Universidade Federal de 
Uberlândia, 2010. Disponível em: < https://repositorio.ufu.br/handle/123456789/5164/simplesearch?filterquery=Lima\%2C+D\%C3\%A9bora+Juliene+Pereira\&filtername=author\&fi Itertype=equals $>$ Acesso em: 04 ago. 2019

MARX, Karl. O capital. Crítica da Economia Política. São Paulo: Editora Nova Cultural, 1996.

MORAES, Márcia Azanha Ferraz Dias de. Indicadores do mercado de trabalho do sistema agroindustrial da cana-de-açúcar do Brasil no período 1992-2005. Estudos Econômicos (São Paulo), v. 37, n. 4, p. 875-902, 2007a. Disponível em: < http://www.scielo.br/scielo.php?pid=S0101-41612007000400007\&script=sci_arttext> Acesso em: 01 ago. 2019.

MORAES, Márcia Azanha Ferraz Dias de. 0 mercado de trabalho da agroindústria canavieira: desafios e oportunidades. Econ. Aplic., São Paulo, V.11, n. 4, p. 605-619, outubro-dezembro 2007b. Disponível em:< http://www.scielo.br/pdf/ecoa/v11n4/08.pdf>. Acesso em: 05 jun. 2019.

NOVACANA. Irregularidades trabalhistas são detectadas em usina sucroalcooleira de Frutal (MG). Paraná: Novacana, 2018. Disponível em: $<$ https://www.novacana.com/n/cana/trabalhadores/irregularidades-trabalhistas-usinasucroalcooleira-frutal-mg-060718>. Acesso em: 05 ago. 2019.

OLIVEIRA, Fabrício Augusto de. Schumpeter: a destruição criativa e a economia em movimento. 2014. Revista de História Econômica \& Economia Regional

Aplicada. v. 10, n. 16, 2014. Disponível em: <

http://www.ufjf.br/heera/files/2009/11/SchumpeterUFJF-2-para-pdf.pdf> Acesso em: 12 ago. 2019.

PRADO JÚNIOR, Caio. Formação do Brasil contemporâneo: colônia. São Paulo: Companhia das Letras, 446 p., 2011.

PREBISCH, Raúl. O desenvolvimento econômico da América Latina e alguns de seus problemas principais. En: Cinqüenta anos de pensamento na CEPAL - Rio de Janeiro: Record/CEPAL, 2000-v. 1, p. 69-136, 2000. Disponível em: $<$ https://repositorio.cepal.org/handle/11362/1611> Acesso em: 05 ago. 2019.

RAMALHO, Claudilene da Costa. Os migrantes cortadores de cana do Vale do Jequitinhonha: entre a superexploração e a resistência. Dissertação de Mestrado. Universidade Federal do Espírito Santo. 2014. Disponível em: <http://repositorio.ufes.br/jspui/handle/10/2608> Acesso em: 01 ago. 2019.

RAMOS, Pedro. O futuro da ocupação na agroindústria canavieira do Brasil: uma discussão dos trabalhos disponíveis e um exercício de estimação. Informações Econômicas, São Paulo, v. 37, n. 11, p. 69-75, 2007. Disponível em: < ftp://ftp.sp.gov.br/ftpiea/publicacoes/tec6-1107.pdf> Acesso em: 15 ago. 2019.

REPORTER BRASIL. As condições de trabalho no setor sucroalcooleiro. Disponível em: <https://reporterbrasil.org.br/wp-content/uploads/2015/02/26.Folder_Sucroalcooleiro_web_baixa.pdf>. Acesso em: 05 ago. 2019. 
Revista Produção Online. Florianópolis, SC, v. 18, n. 2, p. 743-769, 2018.

Disponível em: <https://producaoonline.org.br/rpo/article/view/2967>. Acesso em: 07 ago. 2019

RIBEIRO, Helena; FICARELLI, Thomas Ribeiro de Aquino. Queimadas nos canaviais e perspectivas dos cortadores de cana-de-açúcar em Macatuba, São

Paulo. Saúde e sociedade, v. 19, p. 48-63, 2010. Disponível em: <

https://www.scielosp.org/scielo.php?pid=S0104-

12902010000100005\&script=sci_abstract> Acesso em: 28 jul. 2019.

SANTOS, Anselmo Luis dos Santos; GIMENEZ, Denis Maracci. Desenvolvimento, competitividade e a reforma trabalhista. In: KREIN, Dari José (org.). Dimensões críticas da reforma trabalhista no Brasil. Campinas, SP: Curt Nimuendajú, 2018. P. 27-67. Disponível em: <

https://www.eco.unicamp.br/images/arquivos/LIVRODimensoes-Criticas-da-ReformaTrabalhista-no-Brasil.pdf >. Acesso em: 14 ago. 2019.

SCHUMPETER, Joseph A. Capitalismo, socialismo e democracia. Editora Fundo de Cultura, Rio de Janeiro, 1961.

SCHWARTZ, Stuart. O Brasil Colonial, c. 1580-1750: As Grandes Lavouras e a Periferia In: História da América Latina Colonial. Vol. II. São Paulo: EDUSP; Brasília: FUNAG, 2004. p. 339-421.

SCOPINHO, Rosemeire Aparecida; EID, Farid; VIAN, Carlos Eduardo de Freitas and SILVA, Paulo Roberto Correia da. Novas tecnologias e saúde do trabalhador: a mecanização do corte da cana-de-açúcar. Cad. Saúde Pública [online]. 1999, vol.15, n.1, pp.147-162. Disponível em: $<$ http://www.scielo.br/scielo.php?pid=S0102311X1999000100015\&script=sci_abstract\&tlng=pt. Acesso em: 03 ago. 2019

TEODÓSIO, Armindo dos Santos de Sousa; BARBIERI, José Carlos; CSILLAG, João Mário. Sustentabilidade e competitividade: novas fronteiras a partir da gestão ambiental. Revista Ibero Americana de Estratégia, v. 5, n. 1, p. 37-49, 2006. Disponível em: <https://www.redalyc.org/pdf/3312/331227107004.pdf>. Acesso em: 14 ago. 2019.

TORQUATO, Sergio Alves. Mecanização da colheita da cana-de-açúcar: benefícios ambientais e impactos na mudança do emprego no campo em São Paulo,

Brasil. Revista Brasileira de Ciências Ambientais (Online), n. 29, p. 49-62, 2013. Disponível em: < http://rbciamb.com.br/index.php/Publicacoes_RBCIAMB/article/view/277> Acesso em: 05 ago. 2019.

VIEIRA, José Eustáquio Ribeiro; SILVEIRA, José Maria Ferreira Jardim da. Competências organizacionais, trajetória tecnológica e aprendizado local na agricultura: o paradoxo de Prebisch. Economia e Sociedade, v. 25, n. 3, p. 599630, 2016. Disponível em: <http://www.scielo.br/scielo.php?pid=S010406182016000300599\&script=sci_arttext\&tlng=pt> Acesso em: 05 ago. 2019.

WISSMANN, Martin Airton; SHIKIDA, Pery Francisco Assis. Impactos econômicos, ambientais e sociais da agroindústria canavieira no Brasil. Desenvolvimento, 
Fronteiras E Cidadania, v. 1, n. 1, p. 134-160, 2017. Disponível em: <https://periodicosonline.uems.br/index.php/fronteiracidadania/article/view/2178> Acesso em: 14 ago. 2019.

Recebido em: abril de 2020

Aceito em: junho de 2020 